\title{
MICRORNAS AS BIOMARKERS IN ALCOHOL USE DISORDER: FROM DIAGNOSTICS TO THERAPY. REVIEW OF LITERATURE
} MIKRORNA JAKO BIOMARKERY W ZABURZENIACH ZWIAZZANYCH Z UŻYWANIEM ALKOHOLU: OD DIAGNOSTYKI DO TERAPII. PRZEGLĄD LITERATURY

\author{
Anna Mach ${ }^{1}$ ID, Grażyna Gromadzka² ID \\ ${ }^{1}$ Chair and Department of Psychiatry, Medical University of Warsaw, Poland \\ ${ }^{2}$ Faculty of Medicine, Collegium Medicum, Cardinal Stefan Wyszynski University, Warsaw, Poland \\ ${ }^{1}$ Katedra i Klinika Psychiatryczna, Warszawski Uniwersytet Medyczny, Polska \\ ${ }^{2}$ Wydział Medyczny, Collegium Medicum, Uniwersytet Kardynała Stefana Wyszyńskiego, Warszawa, Polska
}

Alcohol Drug Addict 2020; 33 (4): 313-340 DOI: https://doi.org/10.5114/ain.2020.104815

\begin{abstract}
The aim of this paper is to present the current state of knowledge about microRNAs in alcohol use disorder (AUD). Particular emphasis was placed on estimating the possibility of using microRNA molecules as biomarkers of diagnostic, prognostic and predictive significance as well as potential therapeutic targets in alcohol-related disorders. For this purpose the PubMed, Science Direct and Wiley Online Library medical databases were reviewed using the following phrases: "ncRNA", "microRNA", "circulating microRNA", "miRNA", "alcohol use disorder", "alcohol addiction", "alcohol abuse", "alcoholism", "bio-
\end{abstract}

\section{Streszczenie}

Celem pracy jest przedstawienie aktualnego stanu wiedzy dotyczącego mikroRNA w zaburzeniach związanych z używaniem alkoholu (AUD). Nacisk położono na oszacowanie możliwości wykorzystania cząsteczek mikroRNA jako biomarkerów o znaczeniu diagnostycznym, prognostycznym, predykcyjnym, a także jako potencjalnych celów terapeutycznych $\mathrm{w}$ zaburzeniach związanych $\mathrm{z}$ alkoholem. W tym celu przeszukano medyczne bazy danych PubMed, Science Direct oraz Wiley Online Library z użyciem następujących słów kluczowych: "ncRNA”, „microRNA”, „circulating microRNA”, „miRNA”, „alcohol use disorder”, „al-

Correspondence to/Adres do korespondencji: Anna Mach, Katedra i Klinika Psychiatryczna, Warszawski Uniwersytet Medyczny, ul. Nowowiejska 27, 00-665 Warszawa, Poland, phone: +48 2282512 36, e-mail: anna.mach@wum.edu.pl

Authors' contribution/Wkład pracy autorów: Study design/Koncepcja badania: A. Mach; Data collection/Zebranie danych: A. Mach; Data interpretation/Interpretacja danych: A. Mach, G. Gromadzka; Acceptance of final manuscript version/Akceptacja ostatecznej wersji pracy: A. Mach, G. Gromadzka; Literature search/Przygotowanie literatury: A. Mach

No ghostwriting and guest authorship declared./Nie występują zjawiska ghostwriting i guest authorship.

Submitted/Otrzymano: 06.05.2020 • Accepted/Przyjęto do druku: 16.07.2020

(c) 2020 Institute of Psychiatry and Neurology. Production and hosting by Termedia sp. z o.o.

This is an open access article under the CC BY-NC-ND license (http://creativecommons.org/licenses/by-nc-nd/4.0/) 
marker" and their combinations. Experimental and clinical studies results as well as review papers published in 1993, 1999 and between 2003 and 2020 were selected.

MicroRNAs are small, non-coding oligonucleotides regulating the expression of many genes that play an important role in alcohol use disorder. The review of scientific literature shows that circulating microRNAs can play the role of molecular biomarkers useful in diagnostic and clinical practice. Intensive research is currently being conducted to determine specific microRNAs expression profiles correlated with phenotype, clinical course, degree of organ damage or disease severity. Additionally, microRNAs are also a new, promising target for the development of personalised therapeutic strategies.

Keywords: MicroRNA, Non-coding RNA, Circulating microRNA, Alcohol use disorder, Biomarkers.

\section{- INTRODUCTION}

Alcohol use disorder (AUD) is a serious health, social and economic problem. According to the World Health Organization (WHO), harmful alcohol consumption in European Union countries is the third most important premature death risk factor [1]. The State Agency for the Prevention of Alcohol-Related Problems (PARPA) estimates that there are 2-2.5 million harmful drinkers in Poland, and approximately 800 thousand alcohol dependent persons [2].

Technological achievements have created new possibilities for the detection of genetic, epigenetic and transcriptomic biomarkers. One of the landmark achievements in recent years is the discovery of non-coding RNAs (ncRNA). This has changed the previous concept of RNA as a copy of genomic DNA responsible for transmitting information from genome to protein. It has been shown that ncRNAs, although not a matrix for protein synthesis, are essential for normal physical development and function [3]. It is estimated that only $1.5-2 \%$ of the human genome has the capacity to encode proteins, whereas as many as approx. $90 \%$ of genomic sequences are tran- cohol addiction”, „alcohol abuse”, „alcoholism”, „biomarker” oraz ich kombinacji. Wyodrębniono badania doświadczalne, kliniczne i prace poglądowe, których wyniki były publikowane w latach 1993, 1999 oraz 2003-2020.

MikroRNA są małymi, niekodującymi oligonukleotydami, które regulują ekspresję wielu genów odgrywających istotną rolę w zaburzeniach związanych $\mathrm{z}$ używaniem alkoholu. $\mathrm{Z}$ analizy literatury naukowej wynika, że krążące mikroRNA mogą pełnić funkcję biomarkerów molekularnych użytecznych w praktyce diagnostyczno-klinicznej. Prowadzone są intensywne badania w celu określenia konkretnych profili ekspresji mikroRNA skorelowanych $\mathrm{z}$ fenotypem, przebiegiem klinicznym, stopniem uszkodzenia narządów czy zaawansowania choroby. Ponadto mikroRNA stanowią także nowy, obiecujący cel rozwoju spersonalizowanych strategii terapeutycznych.

Słowa kluczowe: mikroRNA, niekodujące RNA, krążące mikroRNA, zaburzenia związane z używaniem alkoholu, biomarkery.

\section{- WPROWADZENIE}

Zaburzenia związane $\mathrm{z}$ używaniem alkoholu (AUD) są poważnym problemem zdrowotnym, społecznym i ekonomicznym. Według Światowej Organizacji Zdrowia (WHO) szkodliwe spożywanie alkoholu w krajach Unii Europejskiej jest trzecim w kolejności najistotniejszym czynnikiem ryzyka przedwczesnej śmierci [1]. Państwowa Agencja Rozwiązywania Problemów Alkoholowych (PARPA) szacuje, że w Polsce jest 2-2,5 miliona osób pijących szkodliwie i ok. 800 tysięcy osób uzależnionych od alkoholu [2].

Osiągnięcia technologiczne stworzyły nowe możliwości wykrywania biomarkerów genetycznych, epigenetycznych i transkryptomicznych. Jednym $\mathrm{z}$ przełomowych dokonań ostatnich lat jest odkrycie niekodujących RNA (ncRNA). Zmieniło to dotychczasową koncepcję postrzegającą RNA jako kopię genomowego DNA, odpowiedzialną za przenoszenie informacji z genomu do białka. Udowodniono, że ncRNA, chociaż nie stanowią matrycy do syntezy białka, mają zasadnicze znaczenie dla prawidłowego rozwoju i funkcjonowania organizmu [3]. Szacuje się, że tylko 1,5-2\% ludzkiego genomu ma zdolność do kodowania białek, natomiast aż ok. 
scribed into the strand of ncRNA [4]. The most commonly occuring in cells and so far best known ncRNAs are short microRNAs (miRNAs, miRs) the role of which is to regulate gene expression. The discovery of these molecules has contributed to a change in views on many disease processes. MicroRNAs are attributed to participate in the pathogenesis of many diseases, including cancer, cardiovascular, autoimmune, neurological and psychiatric diseases [5-8]. Characteristic changes in miRNA expression have also been observed in nicotine [9], morphine [10] and cocaine [11] dependence as well as alcohol use disorder (AUD) $[12,13]$. Alcohol dependence is a polygenic disease in which the expression of approximately several hundred genes and many miRNAs are altered simultaneously. It has been shown that miRNAs, the expression of which is altered in the brain tissue of alcohol-dependent individuals, are take part in modulating the expression of genes that encode products involved in cell cycle control, cell adhesion, apoptosis, signalling and genes the products of which play a key role in central nervous system (CNS) development and synaptogenesis [14]. The consequences of these changes are permanent modifications in brain centres at the structural, functional and neuroplastic levels [15]. Due to their ability to modulate the expression of genes relevant to the development of alcohol dependence, miRNA molecules appear to be excellent candidates as useful biomarkers with diagnostic, prognostic and even therapeutic values.

The aim of this study is to present the current state of knowledge regarding changes in miRNA expression in alcohol use disorders. The data is presented in terms of potential usefulness in diagnosis and new therapeutic possibilities.

A systematic review of the literature in PubMed, Science Direct and Wiley Online Library databases was the basis for the assessment of the current state of knowledge. In order to extract all publications dealing with changes in miRNA expression in alcohol use disorders, the selected sources were chosen on the basis of keywords like: "ncRNA", "microRNA", "circulating microRNA", "miRNA", "alcohol use disorder", "alcohol addiction", "alcohol abuse", "alcoholism", "biomarker" and their combinations. More than a thousand (1255) papers were found and the bibliography of the extracted
90\% sekwencji genomowych zostaje przepisana na nić ncRNA [4]. Najpowszechniej występującymi w komórkach i zarazem najlepiej poznanymi ncRNA są krótkie mikroRNA (miRNA, miR), których rolą jest regulacja ekspresji genów. Odkrycie tych cząstek przyczyniło się do zmiany poglądów na temat wielu procesów chorobowych. MikroRNA przypisuje się udział $\mathrm{w}$ patogenezie wielu chorób, w tym nowotworowych, sercowo-naczyniowych oraz o podłożu autoimmunologicznym, neurologicznym i psychicznym [5-8]. Charakterystyczne zmiany w ekspresji miRNA obserwowano również w uzależnieniu od nikotyny [9], morfiny [10], kokainy [11], a także w zaburzeniach związanych z używaniem alkoholu (AUD) [12, 13]. Uzależnienie od alkoholu jest chorobą wielogenową, w której dochodzi do jednoczesnej zmiany ekspresji około kilkuset genów i wielu miRNA. Udowodniono, że miRNA, których ekspresja zmienia się w tkance mózgowej osób uzależnionych od alkoholu, biorą udział w modulacji ekspresji genów kodujących produkty uczestniczące $\mathrm{w}$ regulacji cyklu komórkowego, adhezji komórek, apoptozy, sygnalizacji oraz genów, których produkty odgrywają kluczową rolę $\mathrm{w}$ rozwoju ośrodkowego układu nerwowego (OUN) i w synaptogenezie [14]. Konsekwencją tych zmian są trwałe modyfikacje w ośrodkach mózgowych na poziomie strukturalnym, funkcjonalnym i neuroplastycznym [15]. Ze względu na zdolność modulacji ekspresji genów istotnych $\mathrm{w}$ rozwoju uzależnienia od alkoholu cząsteczki miRNA wydają się doskonałymi kandydatami na użyteczne biomarkery o wartościach diagnostycznych, prognostycznych, a nawet terapeutycznych.

Celem pracy jest przedstawienie aktualnego stanu wiedzy $\mathrm{z}$ zakresu zmian w ekspresji miRNA w zaburzeniach związanych $\mathrm{z}$ używaniem alkoholu. Dane zostały przedstawione pod względem potencjalnej użyteczności w diagnostyce i nowych możliwości terapeutycznych.

Podstawą do dokonania oceny aktualnego stanu wiedzy był systematyczny przegląd piśmiennictwa w bazach danych: PubMed, Science Direct oraz Wiley Online Library. W celu wyodrębnienia wszystkich publikacji dotyczących zmian w ekspresji miRNA w zaburzeniach związanych z używaniem alkoholu wybrane źródła zostały wyłonione na podstawie takich słów i haseł kluczowych, jak: „ncRNA”, "microRNA”, „circulating microRNA”, „miRNA”, „alcohol use disorder”, „alcohol addiction”, „alcohol abuse”, „alcoholism”, „,biomarker”, oraz ich kombina- 
articles was analysed. The focus was on sources that met the following criteria: 1) review papers, 2 ) retrospective and prospective studies, 3 ) clinical reports on etiopathogenesis, diagnosis and therapy. Finally, 128 experimental and clinical studies and review papers published in 1993, 1999 and 2003-2020 were qualified for the review and synthesis of conclusions. The papers from 1993 and 1999 are cited to provide a historical outline and to introduce the reader to the presented issue.

\section{- LITERATURE REVIEW}

\section{Biogenesis and functions of microRNAs}

The first miRNA was discovered in 1993. Lee et al. observed that small RNA molecules lin-4, associated with the developmental stages of the nematode Caenorhabditis elegans, modulate the expression of lin-14 protein without affecting its messenger RNA (mRNA) level [16]. The sequence of these molecules was complementary to that of the 3' untranslated region (3'UTR) of the lin-14 gene. In subsequent studies of $C$. elegans another RNA molecule was observed, described as let-7. The newly discovered small RNAs lin-4 and let-7 were named miRNAs. The discovery of their role in regulating gene expression initiated studies to understand their biogenesis and function $[17,18]$.

It is now known that miRNAs are endogenous, single-stranded, non-coding RNA molecules 19-25 nucleotides in length. They act as post-transcriptional regulators of expression of many genes by binding to the non-coding 3'UTR mRNA region. The consequence of this process is mRNA degradation and inhibition of translation and protein production [17].

MicroRNAs are encoded especially in the intergenic regions or within introns, but also in exons of protein-coding genes. They are transcribed in the nucleus by RNA polymerase II (Pol II), resulting in creating primary transcripts $\geq 1000$ base pairs (bp) long called pri-miRNAs. Pri-miRNA, with the involvement of the Drosha and Dicer enzymes, transformed into the double-stranded hairpin structure pre-miRNA and then into single-stranded mature miRNA [19]. The mature miRNA, together with the Argonaute protein, is incorporated into the RISC (RNA-induced silencing complex) silencing gene expres- cji. Znaleziono 1255 prac, a także przeanalizowano bibliografię wyodrębnionych artykułów. Skupiono się na źródłach, które spełniały następujące kryteria: 1) prace poglądowe, 2) badania retrospektywne i prospektywne, 3) doniesienia kliniczne dotyczące etiopatogenezy, diagnostyki i terapii. Ostatecznie do przeglądu i syntezy wniosków zakwalifikowano 128 badań doświadczalnych, klinicznych i prac poglądowych, publikowanych w latach 1993, 1999 oraz 2003-2020. Prace z lat 1993 i 1999 przytoczono w celu przedstawienia rysu historycznego oraz wprowadzenia czytelnika w prezentowane zagadnienie.

\section{- Przegląd Literatury}

\section{Biogeneza i funkcje mikroRNA}

Pierwszy miRNA odkryto w 1993 roku. Lee i wsp. zaobserwowali, że małe cząsteczki RNA lin4, związane z etapami rozwoju nicieni Caenorhabditis elegans, modulują ekspresję białka lin-14 bez wpływu na jego poziom mRNA [16]. Sekwencja tych cząsteczek była komplementarna do sekwencji regionu 3' nieulegającego translacji (3'UTR) genu lin-14. W kolejnych badaniach C. elegans zaobserwowano inną cząsteczkę RNA, opisaną jako let-7. Nowo odkryte małe RNA lin-4 i let-7 nazwano miRNA. Odkrycie ich roli w regulacji ekspresji genów zapoczątkowało badania mające na celu poznanie ich biogenezy i funkcji $[17,18]$.

Obecnie wiadomo, że miRNA są endogennymi, jednoniciowymi, niekodującymi cząsteczkami RNA o długości 19-25 nukleotydów. Działają jako potranskrypcyjne regulatory ekspresji wielu genów przez wiązanie się z niekodującym regionem 3'UTR mRNA. Konsekwencją tego procesu jest degradacja mRNA oraz zahamowanie translacji i produkcji białek [17].

MikroRNA kodowane są zwłaszcza w regionach międzygenowych lub w obrębie intronów, ale także w eksonach genów kodujących białka. Transkrybowane są $\mathrm{w}$ jądrze przez polimerazę II RNA (Pol II), w wyniku czego powstają pierwotne transkrypty o długości $\geq 1000$ par zasad (pz), zwane pri-miRNA. Pri-miRNA, przy udziale enzymów Drosha i Dicer, ulega przekształceniu w dwuniciową strukturę szpilki do włosów pre-miRNA, a następnie w jednoniciowe dojrzałe miRNA [19]. Dojrzała postać miRNA wraz z białkiem Argonaute zostaje włączona do kompleksu RISC wyciszającego ekspresję genów. Konsekwencją tego działania jest zahamo- 
sion. The consequence of this action is inhibition of protein synthesis or mRNA degradation [20]. The process of mRNA degradation involves specific deadenylase complexes that remove the 5' mRNA cap. Molecules lacking protection (5' cap) are rapidly degraded by 5 '-3' exoribonucleases $[17,21,22]$.

According to miRBase data (http://mirbase.org/ index.shtml), more than 2800 mature miRNAs have been identified in humans. Sequencing method studies of RNAs from 13 different types of human tissues revealed as many as 3700 of these molecules [23]. The discovery of such a large number of miRNAs raises many questions, including the most intriguing about the biological function of individual molecules. So far, the exact mechanism, directions and scope of miRNA action have not yet been fully understood. It is known that the binding of miRNA to the 3'UTR mRNA region results in mRNA degradation, inhibition of protein translation and production. As supposed, in this mechanism, at the post-transcriptional or translational level, miRNAs regulate the expression of about $50 \%$ of protein-coding genes [24]. Due to its pleiotropic nature, one miRNA molecule can regulate more than one gene of a given biological pathway, but also multiple miRNA molecules can participate in the regulation of expression of a single gene [25]. It is believed that miRNAs can not only downregulate but also upregulate the expression of target genes [26].

It has been shown that miRNA molecules in some species including Homo sapiens are evolutionarily highly conservative. Among the newly discovered miRNAs by Londin et al. as many as $56.7 \%$ had human-specific sequences [23]. Additionally, miRNAs have high tissue and developmental stage specificity [27]. They are key regulators of important cellular processes like development, proliferation, differentiation, apoptosis or stress response [28]. They are abundant in the brain, where they play important roles in neuronal differentiation and survival $[29,30]$, brain development [31], neuroplasticity or synapse function [32]. The deletion of Dicer, one of the enzymes involved in miRNA biogenesis, has been shown to lead to deficits in brain development, neuronal atrophy and malformations and even premature death [33]. Thus, miRNAs may play a key role in the pathogenesis of nervous system developmental disorders, neurode- wanie syntezy białka lub degradacja mRNA [20]. Proces degradacji mRNA angażuje specyficzne kompleksy deadenylaz, usuwające czapeczkę 5' mRNA. Cząsteczki pozbawione ochrony (czapeczki 5') szybko ulegają degradacji przez 5'-3' eksorybonukleazy [17, 21, 22].

Zgodnie $\mathrm{z}$ danymi miRBase (http://mirbase.org/ index.shtml) u człowieka zidentyfikowano ponad 2800 dojrzałych miRNA. Badania metodą sekwencjonowania RNA pochodzących z 13 różnych rodzajów tkanek ludzkich wykazały aż 3700 tych cząsteczek [23]. Odkrycie tak dużej liczby miRNA rodzi wiele pytań, w tym najbardziej intrygujące: jaką funkcję biologiczną pełnią poszczególne cząsteczki. Dotąd dokładny mechanizm, kierunki i zakres działania miRNA nie zostały jeszcze $w$ pełni poznane. Wiadomo, że w wyniku wiązania miRNA $\mathrm{z}$ regionem 3 'UTR mRNA dochodzi do degradacji mRNA oraz zahamowania translacji i produkcji białka. Jak się przypuszcza, $w$ tym mechanizmie, na poziomie potranskrypcyjnym lub translacyjnym, miRNA regulują ekspresję ok. 50\% genów kodujących białka [24]. Ze względu na plejotropowy charakter jedna cząsteczka miRNA może regulować większą liczbę genów danego szlaku biologicznego, ale również wiele cząsteczek miRNA może uczestniczyć w regulacji ekspresji jednego genu [25]. Uważa się, że miRNA są w stanie nie tylko obniżać, lecz także podwyższać ekspresję genów docelowych [26].

Wykazano, że cząsteczki miRNA u niektórych gatunków, w tym u Homo sapiens, są ewolucyjnie wysoce konserwatywne. Wśród nowo odkrytych miRNA przez Londin i wsp. aż 56,7\% miało sekwencje specyficzne dla człowieka [23]. Dodatkowo miRNA charakteryzują się wysoką specyficznością w stosunku do tkanki i stadium rozwojowego [27]. Są kluczowymi regulatorami ważnych procesów komórkowych, takich jak rozwój, proliferacja, różnicowanie, apoptoza czy odpowiedź na stres [28]. Licznie występują w mózgu, gdzie odgrywają ważną rolę w różnicowaniu i przeżywalności neuronów [29, 30], rozwoju mózgu [31], neuroplastyczności czy funkcji synaps [32]. Wykazano, że usunięcie Dicer, jednego $\mathrm{z}$ enzymów zaangażowanych w biogenezę miRNA, prowadzi do deficytów w rozwoju mózgu, zaniku neuronów i wad rozwojowych, a nawet przedwczesnej śmierci [33]. W związku z tym miRNA mogą odgrywać kluczową rolę $\mathrm{w}$ patogenezie zaburzeń rozwojowych układu nerwowego, 
generative diseases, mental disorders and addictions.

MicroRNAs in the neurobiology of alcohol use disorders

Alcohol use disorders (AUDs) are multifactorial diseases. The risk of developing dependence is determined by the interplay of individual genetic predisposition, environmental factors and neuroadaptive processes following a period of intoxication. Ethyl alcohol, as a substance with significant impact on the CNS, modulates the activity of various neurotransmitter pathways and ion channels. The consequences of long-term intoxication are modifications in gene expression that may lead to the development of tolerance, compulsive drinking and dependence [34]. Research on this topic suggests that regulatory miRNA molecules are involved in the neurobiology of AUD [35]. It has been demonstrated that miRNAs can modulate receptors, ion channels and membrane transporters responsible for the uptake of neurotransmitters from the synaptic cleft. In an experimental model of alcohol dependence, it was shown that the miR-382 molecule negatively regulates the expression of dopamine $D_{1}$ receptors (DRD1). Thus, there is an attenuation of the alcohol-induced increase in the DeltaFosB transcription factor that plays an important role in the rewarding effect of alcohol [36]. Increased expression and/or activation of DRD1 in the CNS has been observed in animals after alcohol consumption [37]. DRD1 blocking by the agonist was sufficient to inhibit alcohol-related dependent behaviour [38]. In a similar way, the expression of NMDA (N-methyl-D-aspartate) receptors in hippocampal neurons is regulated by miR-19a, miR-223 and miR-539 molecules [39]. In contrast, miR-124, miR-223 and miR-181 regulate the GluA2 subunit of the AMPA ( $\alpha$-amino-3-hydroxy-5-methylisoxazole-4-propionic acid) receptor [40-42]. The serotonin system important in the pathomechanism of dependence development is also subject to miRNA regulation. The best known miRNAs affecting serotonergic transmission are miR-16, miR-135 and miR-15a $[43,44]$. Their target remains mainly the serotonin transporter (SERT), but also the serotonin receptor 5-HT1AR. The study by Baudry et al. shows that miR-16 controls SERT synthesis. Fluoxetine administration increased chorób neurodegeneracyjnych, psychicznych oraz uzależnień.

\section{MikroRNA w neurobiologii zaburzeń związanych z używaniem alkoholu}

Zaburzenia związane $\mathrm{z}$ używaniem alkoholu (AUD) należą do chorób uwarunkowanych wieloczynnikowo. Ryzyko rozwoju uzależnienia jest określane jako wynik wzajemnego oddziaływania indywidualnych predyspozycji genetycznych, czynników środowiskowych i procesów neuroadaptacyjnych zachodzących po okresie intoksykacji. Alkohol etylowy, jako substancja o znaczącym wpływie na OUN, moduluje aktywność różnych szlaków neuroprzekaźnikowych oraz kanałów jonowych. Konsekwencją długotrwałej intoksykacji są modyfikacje w ekspresji genów, które mogą prowadzić do rozwoju tolerancji, kompulsywnego spożywania i uzależnienia [34]. Badania dotyczące tego tematu sugerują, że regulatorowe cząsteczki miRNA biorą udział w neurobiologii AUD [35]. Udowodniono, że miRNA mogą modulować receptory, kanały jonowe i transportery błonowe odpowiedzialne za wychwyt neuroprzekaźników ze szczeliny synaptycznej. W doświadczalnym modelu uzależnienia od alkoholu wykazano, że cząsteczka miR-382 negatywnie reguluje ekspresję receptorów dopaminowych $\mathrm{D}_{1}$ (DRD1). Tym samym dochodzi do osłabienia indukowanego przez alkohol wzrostu czynnika transkrypcyjnego DeltaFosB, który odgrywa ważną rolę w nagradzającym efekcie działania alkoholu [36]. U zwierząt po spożyciu alkoholu obserwowano podwyższoną ekspresję i/lub aktywację DRD1 w OUN [37]. Blokowanie DRD1 przez agonistę było wystarczające do zahamowania związanych $\mathrm{z}$ alkoholem zachowań uzależniających [38]. W podobny sposób ekspresja receptorów NMDA w neuronach hipokampa podlega regulacji przez cząsteczki miR-19a, miR-223 oraz miR-539 [39]. Natomiast miR-124, miR-223 i miR-181 regulują podjednostkę GluA2 receptora AMPA [40-42]. Układ serotoninowy, istotny $\mathrm{w}$ patomechanizmie rozwoju uzależnienia, również podlega regulacji miRNA. Najlepiej poznanymi miRNA wpływającymi na przekaźnictwo serotoninergiczne są miR-16, miR-135 oraz miR-15a [43, 44]. Celem ich działania pozostaje głównie transporter serotoniny (SERT), ale także receptor serotoniny 5-HT1AR. Z badania Baudry i wsp. wynika, że miR-16 kontroluje syntezę SERT. Podanie fluoksetyny wpływało na zwiększe- 
miR-16 expression, which then reduced SERT [45]. The dynamics of receptor expression appears to be an important determinant of synaptic plasticity relevant to the neurobiology of dependence.

An example of a miRNA that modulates ion channels and, at the same time, plays an important regulatory role in neuroadaptation mediating the development of alcohol dependence, is miR-9. As has been shown miR-9 regulates the expression of the KCNMA1 (potassium calcium-activated channel subfamily $M a 1$ ) gene coding voltage- and calcium-gated potassium channels BK, involved in modelling neuronal activity. Unlike other voltage-gated ion channels, BK channels show high sensitivity to ethanol [46]. Excessive alcohol exposure has been observed to increase miR-9 level, while increased numbers of miR-9 molecules promote increased production of BK channels. It is suspected that this mechanism may be responsible for the development of functional alcohol tolerance [12]. This hypothesis was confirmed in an experimental model of Drosophila [47].

Additionally, miRNAs are involved in the regulation of important proteins in AUD such as a-synuclein or brain-derived neurotrophic factor (BDNF). a-synuclein is responsible for the regulation of dopaminergic neurotransmission by affecting the transport and storage of dopamine in neurosecretory vesicles [48], and for the regulation of dopamine biosynthesis itself by inhibiting tyrosine hydroxylase activity [49]; it also plays an important role in shaping synaptic plasticity [50]. Due to these functions, it is considered to be one of the key proteins involved in the etiopathogenesis of neurodegenerative diseases [51]. The expression of $\alpha$-synuclein is modulated by miR-7 and miR-153 molecules [52]. As shown, overexpression of miR-7 and miR-153 decreases endogenous $\alpha$-synuclein level, whereas inhibition of miR-7 and miR-153 increases its translation [52]. It is worth noting that AUD correlates with $\alpha$-synuclein level [53]. BDNF, considered one of the important factors regulating alcohol consumption, is a direct target of many miRNAs [54]. BDNF is found in brain regions of high plasticity responsible for mood, such as the hippocampus, prefrontal cortex and amygdala. The role of BDNF in regulating the reward system and dependence-related behaviours has been repeatedly nie ekspresji miR-16, który następnie redukował SERT [45]. Dynamika ekspresji receptorów wydaje się ważnym czynnikiem decydującym o plastyczności synaptycznej istotnej w neurobiologii uzależnienia.

Przykładem miRNA modulującego kanały jonowe i zarazem odgrywającego ważną rolę regulacyjną w neuroadaptacji pośredniczącej w rozwoju uzależnienia od alkoholu jest miR-9. Udowodniono, że miR-9 reguluje ekspresję genu KCNMA1 kodującego aktywowane napięciem i jonami wapnia kanały potasowe typu BK uczestniczące w modelowaniu aktywności neuronalnej. W odróżnieniu od innych kanałów jonowych bramkowanych napięciem, kanały BK wykazują dużą wrażliwość na etanol [46]. Zaobserwowano, że intensywna ekspozycja na alkohol podwyższa poziom miR-9, natomiast zwiększona liczba cząsteczek miR-9 sprzyja wzmożonej produkcji kanałów BK. Podejrzewa się, że mechanizm ten może być odpowiedzialny za rozwój funkcjonalnej tolerancji na alkohol [12]. Ta hipoteza znalazła potwierdzenie $\mathrm{w}$ doświadczalnym modelu Drosophila [47].

Dodatkowo miRNA uczestniczą $\mathrm{w}$ regulacji istotnych w AUD białek, takich jak a-synukleina czy czynnik neurotroficzny pochodzenia mózgowego (BDNF). a-synukleina odpowiada za regulację neurotransmisji dopaminergicznej przez wpływ na transport i magazynowanie dopaminy w pęcherzykach neurosekrecyjnych [48], a także za regulację biosyntezy samej dopaminy przez hamowanie aktywności hydroksylazy tyrozynowej [49]; odgrywa również ważną rolę $\mathrm{w}$ kształtowaniu plastyczności synaptycznej [50]. Z uwagi na pełnione funkcje uważana jest za jedno $\mathrm{z}$ kluczowych białek zaangażowanych w etiopatogenezę chorób neurodegeneracyjnych [51]. Ekspresję a-synukleiny modulują cząsteczki miR-7 oraz miR-153 [52]. Jak wykazano, nadekspresja miR-7 i miR-153 obniża poziom endogennej a-synukleiny, podczas gdy inhibicja miR-7 oraz miR-153 zwiększa jej translację [52]. Warto podkreślić, że AUD koreluje z poziomem $\alpha$-synukleiny [53]. BDNF, uważany za jeden $\mathrm{z}$ istotnych czynników regulujących spożycie alkoholu, jest bezpośrednim celem działania wielu miRNA [54]. BDNF występuje w rejonach mózgu o wysokiej plastyczności odpowiedzialnych za nastrój, takich jak hipokamp, kora przedczołowa czy ciało migdałowate. Wielokrotnie potwierdzono rolę $\mathrm{BDNF} \mathrm{w}$ regulowaniu układu nagrody oraz zachowań związanych z uzależnieniami [55]. 
confirmed [55]. Decreased BDNF concentrations have been observed in alcohol-dependent individuals [56]. A study by Bahi, using an animal model, confirmed a direct effect of miR-124a on BDNF expression in the hippocampal region [57]. This finding suggests the involvement of miR-124a in neuroadaptive processes underlying the development of alcohol dependence. Additionally, an effect of alcohol is an increase in the expression of the miR-206 molecule in the medial prefrontal cortex (mPFC). Thus, miR-206 contributes to the down-regulation of the transcript level encoding BDNF. In contrast, inhibition of miR-206 expression significantly increases the level of BDNF produced [58]. It is supposed that long-term induction of miR-206 expression and its effect on BDNF regulation may alter the function of neural circuits involved in the control of alcohol consumption, which may accordingly affect the development of dependence. As demonstrated by Darcq et al., the miR-30a-5p molecule also regulates BDNF transcription. Importantly, an increase in miR-30a-5p in the $\mathrm{mPFC}$ decreased BDNF expression, resulting in an increase in the intensity of alcohol consumption. Thus, miR-30a-5p has been shown to be involved in the transition from moderate to excessive alcohol consumption [59].

The role of miRNAs in AUD neurobiology may be influenced by the involvement of these molecules in the processes associated with psychological stress. It has been demonstrated that under stress, the expression of miRNAs (such as miR-10a, miR-21) and their target genes (RPL9, RPS3A, RPS17, RPL31) is altered [60, 61]. As shown, the expression of miR-10a and miR-21 increases after exposure to stress and correlates with the amount of alcohol consumed. Thus, changes in miRNA expression may be one of the mechanisms linking psychological stress with alcohol consumption intensity [61].

\section{MicroRNAs as biomarkers}

A biomarker is a substance derived from biological material that reflects the current stage and progression of a disease as well as the effectiveness of the therapy used [62]. The use of miRNAs as biomarkers began with the observation that miRNAs are tissue specific and their modification is associated with the occurrence of pathological processes [63]. Although most of the identified miRNAs occur intracellularly, the results
U osób uzależnionych od alkoholu obserwowano obniżone stężenie BDNF [56]. Badanie Bahi, z wykorzystaniem modelu zwierzęcego, potwierdziło bezpośredni wpływ miR-124a na ekspresję BDNF $\mathrm{w}$ rejonie hipokampa [57]. Odkrycie to sugeruje zaangażowanie miR-124a w procesy neuroadaptacyjne leżące u podstaw rozwoju uzależnienia od alkoholu. Dodatkowo pod wpływem alkoholu dochodzi do wzrostu ekspresji cząsteczki miR-206 w przyśrodkowej korze przedczołowej (mPFC). W ten sposób miR-206 przyczynia się do obniżenia poziomu transkryptu kodującego BDNF. Natomiast zahamowanie ekspresji miR-206 znacząco zwiększa poziom produkowanego BDNF [58]. Przypuszcza się, że długotrwała indukcja ekspresji miR-206 i jej wpływ na regulację BDNF może zmieniać funkcję obwodów neuronowych zaangażowanych w kontrolę spożywania alkoholu, co w konsekwencji może wpływać na rozwój uzależnienia. Jak udowodnili Darcq i wsp. cząsteczka miR-30a-5p również reguluje transkrypcję BDNF. Co ważne, wzrost miR-30a-5p w mPFC zmniejszał ekspresję BDNF, co skutkowało wzrostem intensywności spożywania alkoholu. Tym samym wykazano, że miR-30a-5p uczestniczy w przejściu od umiarkowanego do nadmiernego spożycia alkoholu [59].

$\mathrm{Na}$ rolę miRNA w neurobiologii AUD może mieć wpływ udział tych cząsteczek w przebiegu procesów związanych ze zjawiskiem stresu psychicznego. Udowodniono, że pod wpływem stresu dochodzi do zmian w ekspresji miRNA (takich jak miR-10a, miR-21) oraz ich genów docelowych (RPL9, RPS3A, RPS17, RPL31) [60, 61]. Jak wykazano, ekspresja miR-10a i miR-21 wzrasta po ekspozycji na stres oraz koreluje $z$ ilością spożywanego alkoholu. Zmiany w ekspresji miRNA mogą więc być jednym $z$ mechanizmów łączących stres psychiczny $z$ nasileniem spożycia alkoholu [61].

\section{MikroRNA jako biomarkery}

Biomarkerem określa się substancję pochodzącą z materiału biologicznego, która odzwierciedla aktualny stan zaawansowania i progresję choroby, a także skuteczność zastosowanej terapii [62]. Wykorzystanie miRNA jako biomarkerów rozpoczęło się od obserwacji, że miRNA są swoiste dla tkanki, a ich modyfikacja związana jest $\mathrm{z}$ występowaniem procesów patologicznych [63]. Pomimo że większość zidentyfikowanych miRNA występuje we- 
of the study confirmed the presence of these molecules also in the extracellular environment. Their occurrence has been demonstrated in blood se$\mathrm{rum} /$ plasma and other body fluids such as saliva, sweat, urine or milk [64]. Extracellular miRNAs are described as circulated miRNAs (c-miRNAs). The primary mechanism of transport of endogenous miRNAs into body fluids is suspected to be their active secretion in microbubbles (mainly exosomes) or in lipoprotein particles: HDL (high density lipoprotein) and LDL (low density lipoprotein). Another miRNA transport mechanism is thought to be passive migration outside the cell as a result of mechanical tissue damage, apoptosis, necrosis or chronic inflammation. A third suggested mechanism is transport of miRNAs with cellular RNA-binding proteins such as nucleophosmin 1 or Argonaute family proteins [65]. This raises the question whether c-miRNA concentrations fully reflect tissue expression level. Previous reports on this issue are inconclusive $[66,67]$.

In recent years, there has been an increased interest in c-miRNAs as regards their utility in diagnostic and clinical practice. This is due to the fact that they have many characteristics of an ideal biomarker. It is worth noting that miRNA expression profiles characteristic for a given disease entity are organ-specific, and disorders diagnosed on their basis are detected with high sensitivity. The expression of miRNAs is often dependent on the type of tissue and the stage of the disease process [68]. Additionally, miRNAs present in peripheral blood are stable and resistant to the activity of enzymes called ribonucleases (RNase) in circulation [69]. Even harsh conditions that degrade most RNAs like extreme $\mathrm{pH}$ values, prolonged storage at room temperature, repeated freezing and thawing do not damage c-miRNAs [70, 71]. It has been demonstrated that even months of storage of serum/plasma obtained from a few millilitres of whole peripheral blood at $-80^{\circ} \mathrm{C}$ does not affect the loss of stability and evaluation of miRNA expression. In contrast to routinely used protein biomarkers, c-miRNAs have far fewer limitations. Compared to proteins, miRNAs do not undergo post-translational modifications, have a much less complex chemical composition and a more stable expression. Furthermore, c-miRNAs can be detected at very low concen- wnątrzkomórkowo, to wyniki badań potwierdziły obecność tych cząsteczek również w środowisku zewnątrzkomórkowym. Ich występowanie wykazano w surowicy/osoczu krwi oraz innych płynach ustrojowych, takich jak ślina, pot, mocz czy mleko [64]. Zewnątrzkomórkowe miRNA określa się mianem krążących miRNA (c-miRNA). Podejrzewa się, że podstawowym mechanizmem transportu endogennych miRNA do płynów ciała jest ich aktywna sekrecja w mikropęcherzykach (głównie egzosomach) lub cząsteczkach lipoprotein HDL i LDL. Za kolejny mechanizm transportu miRNA uważa się bierną migrację na zewnątrz komórki w wyniku mechanicznego uszkodzenia tkanek, apoptozy, nekrozy czy przewlekłego stanu zapalnego. Trzecim sugerowanym mechanizmem jest transport miRNA z komórkowymi białkami wiążącymi RNA, takimi jak nukleofozmina 1 lub białka $\mathrm{z}$ rodziny Argonaute [65]. Nasuwa się pytanie, czy stężenie c-miRNA w pełni odzwierciedla poziom ekspresji w tkankach. Dotychczasowe doniesienia w tej kwestii są niejednoznaczne $[66,67]$.

$\mathrm{W}$ ostatnich latach obserwuje się wzrost zainteresowania c-miRNA pod kątem użyteczności $\mathrm{w}$ praktyce diagnostyczno-klinicznej. Wynika to z faktu, że mają wiele cech idealnego biomarkera. Warto zwrócić uwagę, że charakterystyczne dla danej jednostki chorobowej profile ekspresji miRNA są swoiste narządowo, a zaburzenia diagnozowane na ich podstawie wykrywane są z wysoką czułością. Ekspresja miRNA jest często zależna od rodzaju tkanki i etapu procesu chorobowego [68]. Dodatkowo miRNA obecne we krwi obwodowej są stabilne oraz odporne na działanie enzymów zwanych rybonukleazami występujących w krążeniu [69]. Nawet trudne warunki, które degradują większość RNA, takie jak skrajne wartości pH, długotrwałe przechowywanie $\mathrm{w}$ temperaturze pokojowej, wielokrotne zamrażanie i rozmrażanie, nie powodują uszkodzenia c-miRNA [70, 71]. Udowodniono, że nawet wielomiesięczne przechowywanie surowicy/ osocza uzyskanych z kilku mililitrów pełnej krwi obwodowej $\mathrm{w}$ temperaturze $-80^{\circ} \mathrm{C}$ nie wpływa na utratę stabilności i ocenę ekspresji miRNA. W przeciwieństwie do rutynowo stosowanych biomarkerów białkowych c-miRNA mają znacznie mniej ograniczeń. W porównaniu z białkami miRNA nie ulegają potranslacyjnym modyfikacjom, charakteryzują się znacznie mniej złożonym składem chemicznym i bardziej stabilną ekspresją. Ponadto c-miRNA można wykryć już w bardzo niskich stę- 
trations and their appearance is much faster than proteins, allowing earlier detection and diagnostic use [72]. Additionally, miRNAs can be complementary to protein markers, allowing earlier and more effective diagnosis [73]. The advantage of c-miRNA testing is the availability of biological material.

The aim of this study is to analyse the potential use of miRNAs as biomarkers in alcohol use disorders. It is known that alcohol exposure causes epigenetic modifications, including changes in miRNA expression, which may prove to be a valuable predictive, diagnostic and therapeutic marker [74]. In this context, the discovery that $80 \%$ of genes expressed in brain tissue are also expressed in peripheral blood seems interesting [75]. This indicates the potential use of molecular markers present in serum, plasma or peripheral blood cells as biomarkers in CNS diseases, reflect processes occurring in the brain. Previous findings present c-miRNAs as sensitive and specific biomarkers for many CNS diseases [76, 77]. Additionally, organ-specific miRNAs present in peripheral blood can be regarded as an early indicator of tissue damage under the influence of alcohol toxicity, complementary to protein markers and diagnostic imaging [78].

MicroRNAs in the diagnosis of alcohol use disorders

As miRNAs influence mRNA expression, analysis of the expression pattern can provide valuable information. Appropriately designed miRNA expression profiles may prove to be an independent identification method of clinical process as well as a diagnostic tool to help assess the severity of alcohol-related disorders and organ damage.

To date, characteristic and reproducible miRNA expression profiles have been identified in AUD patients' serum. The most significant differences compared to non-alcohol-dependent individuals were observed in the expression of miR-96, miR-320b-1, miR-1976. Smaller, but also significant differences were found for miR-24-1, miR-30a, miR-92b, miR-96-5p, miR-127, miR-136, miR-301a-3p, miR-320b-2, miR-421, miR-660-5p, miR-671, miR-3615 and miR-3676 [79]. Changes in the expression of the above-mentioned miRNAs have also been reported in brain tissue collected post-mortem from alcohol-dependent patients żeniach, a ich pojawianie się jest znacznie szybsze niż białka, co pozwala na wcześniejsze wykrycie i wykorzystanie diagnostyczne [72]. Dodatkowo miRNA mogą stanowić uzupełnienie dla markerów białkowych, pozwalając na wcześniejszą i bardziej skuteczną diagnostykę [73]. Zaletą badania c-miRNA jest dostępność materiału biologicznego.

Zadaniem niniejszej pracy jest analiza możliwości wykorzystania miRNA jako biomarkerów w zaburzeniach związanych $\mathrm{z}$ używaniem alkoholu. Wiadomo, że ekspozycja na alkohol powoduje modyfikacje epigenetyczne, $w$ tym zmiany $w$ ekspresji miRNA, które mogą okazać się istotnym markerem o wartości predykcyjnej, diagnostycznej i terapeutycznej [74]. W tym kontekście interesujące wydaje się odkrycie, że $80 \%$ genów ulegających ekspresji w tkance mózgowej podlega również ekspresji we krwi obwodowej [75]. Wskazuje to na potencjalne możliwości wykorzystania markerów molekularnych obecnych w surowicy, osoczu lub komórkach krwi obwodowej jako biomarkerów w chorobach OUN, odzwierciedlających procesy zachodzące w mózgu. Dotychczasowe wyniki badań przedstawiają c-miRNA jako czułe i swoiste biomarkery wielu chorób OUN $[76,77]$. Dodatkowo obecne we krwi obwodowej swoiste narządowo miRNA można traktować jako wczesny wskaźnik uszkodzenia tkanek pod wpływem toksycznego działania alkoholu, będący uzupełnieniem dla markerów białkowych i diagnostyki obrazowej [78].

\section{MikroRNA w diagnostyce zaburzeń związanych z używaniem alkoholu}

W związku z tym, że miRNA wywierają wpływ na ekspresję mRNA, analiza wzorca ekspresji może dostarczyć cennych informacji. Odpowiednio opracowane profile ekspresji miRNA mogą okazać się niezależną metodą identyfikacji przebiegu klinicznego, a także narzędziem diagnostycznym pomocnym w ocenie stopnia zaawansowania spowodowanych przez alkohol zaburzeń i uszkodzeń narządów.

Dotychczas w surowicy pacjentów z AUD zidentyfikowano charakterystyczne i powtarzalne profile ekspresji miRNA. Najbardziej znaczące różnice w porównaniu $\mathrm{z}$ osobami nieuzależnionymi od alkoholu odnotowano w zakresie ekspresji miR-96, miR-320b-1 i miR-1976. Mniejsze, ale również istotne różnice wykazano dla miR-24-1, miR-30a, miR-92b, miR-96-5p, miR-127, miR-136, miR-301a-3p, miR-320b-2, miR-421, miR-660-5p, miR-671, miR-3615 i miR-3676 [79]. Zmiany w ekspresji ww. miRNA 
[79]. It is thought that increased expression of the aforementioned miRNAs in AUD may reflect both compensatory mechanisms in response to neuronal damage and excessive release of these molecules from damaged tissues.

In contrast, a study by Darcq et al. reported that miR-30a-5p was a biomarker of prognostic importance. The authors showed that overexpression of this molecule in $\mathrm{mPFC}$ (medial prefrontal cortex) is associated with the occurrence of alcohol abuse phenotype [59]. Excessive alcohol consumption also correlates with the overexpression of other miRNAs such as miR-195, miR-124, miR-1 or miR-206, which target BDNF mRNA. These are thought to play a role in regulating alcohol consumption and uncontrolled drinking behaviour. Interestingly, increased expression of miR-124 in mPFC was detected after 24 hours of abstinence, miR-1 after a session of continuous drinking, and miR-206 three weeks after the end of alcohol exposure $[14,15,58]$. Furthermore, it has been observed that miRNA expression is associated with an increase in neuronal excitability controlling synaptic plasticity [80]. Alcohol withdrawal induces increased neuronal activity in the prefrontal cortex $[81,82]$. Therefore it can be suspected that miRNAs are a determinant of increased neuronal excitability occurring during abstinence.

Rosato et al. were the first to determine the miRNA expression profile in saliva (miR-10a-5p, miR-1290, miR-4488) characteristic of alcohol-dependent patients. They demonstrated that miRNAs derived from saliva can be non-invasive, specific and reliable biomarkers with a predictive value. Based on the analysis of the miRNA profile in sali$\mathrm{va}$, it was possible to estimate alcohol dependence with an accuracy of 79.1\% [83].

Research is also underway to determine the feasibility of using miRNAs as biomarkers of alcohol-related multi-organ damage [84, 85]. The utility of miRNAs as biomarkers has been analysed in alcoholic liver disease (ALD), the spectrum of which ranges both simple alcoholic steatohepatitis (ASH), progressive liver fibrosis, alcoholic cirrhosis and hepatocellular carcinoma $[86,87]$. In an animal model, increases were observed (miR-33, miR-34a, miR-132, miR-155, miR-217, miR-320, miR-486, miR-705, miR-1224) as well as decreases (miR-27b, miR-122, miR-148a, miR-183, miR-199, odnotowano również w tkance mózgowej pobranej pośmiertnie od chorych uzależnionych od alkoholu [79]. Uważa się, że zwiększona ekspresja wymienionych miRNA w AUD może odzwierciedlać zarówno mechanizmy kompensacyjne $\mathrm{w}$ odpowiedzi na uszkodzenie neuronów, jak i nadmierne uwalnianie tych cząsteczek z uszkodzonych tkanek.

Natomiast w badaniu Darcq i wsp. jako biomarker o znaczeniu rokowniczym przedstawiono miR-30a-5p. Autorzy wykazali, że nadekspresja tej cząsteczki w mPFC (przyśrodkowej korze przedczołowej) jest związana $\mathrm{z}$ wystąpieniem fenotypu nadużywania alkoholu [59]. Nadmierne spożywanie alkoholu koreluje $\mathrm{z}$ nadekspresją również innych miRNA, takich jak miR-195, miR-124, miR-1 czy miR-206, celujących w mRNA BDNF. Uważa się, że odgrywają one rolę w regulacji spożywania alkoholu i zachowań związanych z niekontrolowanym piciem. Co ciekawe, zwiększoną ekspresję miR-124 w mPFC wykryto po 24 godzinach abstynencji, miR-1 po sesji ciągłego picia, a miR-206 po trzech tygodniach od zakończeniu ekspozycji na alkohol $[14,15,58]$. Ponadto zaobserwowano, że ekspresja miRNA powiązana jest ze wzrostem pobudliwości neuronalnej kontrolującej plastyczność synaptyczną [80]. Odstawienie alkoholu indukuje zwiększoną aktywność neuronów w korze przedczołowej $[81,82]$. Można zatem podejrzewać, że miRNA są wyznacznikiem zwiększonej pobudliwości neuronów występującej w okresie abstynencji.

Rosato i wsp. pierwsi określili profil ekspresji miRNA w ślinie (miR-10a-5p, miR-1290, miR-4488) charakterystyczny dla pacjentów uzależnionych od alkoholu. Udowodnili, że miRNA pochodzące ze śliny mogą stanowić nieinwazyjne, specyficzne i wiarygodne biomarkery o wartości predykcyjnej. Na podstawie analizy profilu miRNA w ślinie możliwe było oszacowanie uzależnienia od alkoholu z dokładnością do 79,1\% [83].

Prowadzone są również badania mające na celu ustalenie możliwości wykorzystania miRNA jako biomarkerów wielonarządowych uszkodzeń spowodowanych przez alkohol $[84,85]$. Analizowano przydatność miRNA jako biomarkerów w alkoholowej chorobie wątroby (ALD), której spektrum obejmuje zarówno proste alkoholowe stłuszczeniowe zapalenie wątroby (ASH), postępujące włóknienie, marskość wątroby, jak i raka wątrobowokomórkowego [86, 87]. W modelu zwierzęcym zaobserwowano wzrost (miR-33, miR-34a, miR-132, miR-155, miR-217, miR-320, miR-486, miR-705, miR-1224), 
miR-199a-3p, miR-200a, miR-203, miR-214, $\mathrm{miR}-322)$ for the expression of individual miRNA molecules under the influence of long-term ethanol exposure [88-91]. Among the 32 different miRNAs upregulated in alcoholic hepatitis, only four (miR-185, miR-199a-3p, miR-214 and miR-490) showed a similar profile of changes in peripheral blood and liver [92]. It seems that only some c-miRNAs may have diagnostic significance [93].

The observation regarding changes in the expression of miRNAs involved in the processes of alcohol-induced liver cancer development seems relevant $[89,94]$. The results of the study by Meng et al. indicated that miR-34a expression is increased in liver cells subjected to alcohol intoxication. Abnormal expression of this molecule is frequently observed in primary alcoholic liver disease (ALD). Interestingly, miR-34a is involved both in alcoholic liver damage and in the repair of damaged tissues. On the one hand, it increases cell proliferation, survival and migration, which may be important for regression of fibrosis or cirrhosis, and on the other hand, it may enhance neoplastic transformation [89].

When analysing the use of miRNAs as ALD biomarkers, it is important to highlight the existence of a correlation between the expression of some c-miRNAs and the concentration of parameters standardly used in the diagnosis of liver function. In a study by Migit et al., the level of circulating miR-21 and miR-122 correlated with the concentration of AST and ALT liver enzymes [95]. In subsequent reports, circulating miR-122, represents $70 \%$ of all miRNAs in mature hepatocytes, was proposed as a biomarker of hepatocyte injury. Similarly, circulating miR-192 and miR-30a and miR-182 reflect the degree of liver damage so have been presented as potential biomarkers useful in the diagnosis and estimation of ALD severity [96-98]. On the other hand, miRNA-155 which targets are PPAR $\alpha$ and PPAR $\gamma$ (the peroxisome proliferator-activated receptors $\alpha$ and $\gamma$ ), involved in fat metabolism, oxidative stress, inflammation and fibrosis, has been recognised as a marker of inflammation [99]. Increased expression of miR-155 after alcohol exposure has been observed in the liver, as well as in the intestine [100]. It is likely that miR-155 is associated with ale także obniżenie (miR-27b, miR-122, miR-148a, miR-183, miR-199, miR-199a-3p, miR-200a, miR-203, miR-214, miR-322) ekspresji poszczególnych cząsteczek miRNA pod wpływem długotrwałej ekspozycji na etanol [88-91]. Wśród 32 różnych miRNA podlegających regulacji w alkoholowym zapaleniu wątroby tylko cztery (miR-185, miR-199a-3p, miR-214 i miR-490) wykazały podobny profil zmian we krwi obwodowej i w wątrobie [92]. Wydaje się, że tylko niektóre c-miRNA mogą mieć znaczenie diagnostyczne [93].

Istotna wydaje się obserwacja dotycząca zmian ekspresji miRNA zaangażowanych w procesy rozwoju nowotworów wątroby pod wpływem alkoholu [89, 94]. Wyniki badań Meng i wsp. wykazały, że w komórkach wątroby poddanych intoksykacji alkoholowej dochodzi do wzrostu ekspresji miR-34a. Zaburzona ekspresja tej cząsteczki jest często obserwowana $\mathrm{w}$ pierwotnej alkoholowej chorobie wątroby (ALD). Co ciekawe, miR-34a uczestniczy zarówno $\mathrm{w}$ alkoholowym uszkodzeniu wątroby, jak i w naprawie uszkodzonych tkanek. $Z$ jednej strony zwiększa proliferację, przeżycie i migrację komórek, co może być istotne dla regresji zwłóknienia czy marskości wątroby, a z drugiej - może nasilać transformację nowotworową [89].

Analizując wykorzystanie miRNA jako biomarkerów ALD, należy podkreślić występowanie korelacji pomiędzy ekspresją niektórych c-miRNA a stężeniem parametrów standardowo używanych $\mathrm{w}$ diagnostyce funkcji wątroby. W badaniu Migita i wsp. poziom krążących miR-21 i miR-122 korelował ze stężeniem enzymów wątrobowych: AST i ALT [95]. W kolejnych doniesieniach krążący miR-122, stanowiący $70 \%$ wszystkich miRNA w dojrzałych hepatocytach, został zaproponowany jako biomarker uszkodzenia hepatocytów. Podobnie krążące miR-192 i miR-30a oraz miR-182 odzwierciedlające stopień uszkodzenia wątroby zaprezentowano jako potencjalne biomarkery przydatne w diagnostyce oraz oszacowaniu stopnia zaawansowania ALD [96-98]. Natomiast miRNA-155, którego celem są PPARa i PPAR $\gamma$ (receptory aktywowane przez proliferatory peroksysomów a i $\gamma$ ), biorące udział w procesach metabolizmu tłuszczów, stresie oksydacyjnym, stanie zapalnym oraz zwłóknieniu, został uznany za marker stanu zapalnego [99]. Zwiększoną ekspresję miR-155 po ekspozycji na alkohol obserwowano w wątrobie, a także w jelitach [100]. Prawdopodobnie miR-155 ma związek $\mathrm{z}$ chorobami zapalnymi jelit, $\mathrm{w}$ tym $\mathrm{z}$ wrzodzieją- 
inflammatory bowel disease (IBD), including alcohol-induced ulcerative colitis [100].

Excessive alcohol consumption can also lead to pancreatic inflammation and fibrosis [101, 102]. A study in an animal model showed that chronic ethanol administration induced changes in the expression of individual miRNAs in the pancreas. Both increases (miR-21, miR-199a-3p, miR-211) and decreases (miR-148a and miR-802) in miRNA expression were observed [102]. There are data indicating that miR-21 is a molecule involved in the regulation of connective tissue growth factor (CTGF) levels in the course of chronic pancreatitis [103]. Both miR-21 overexpression and elevated connective tissue growth factor levels are involved in pancreatic stellate cell (PSC) activation in alcoholic pancreatitis or pancreatic fibrosis [103, 104]. Clearly, further studies are needed to clarify whether miR-21 is a useful biomarker to determine the severity of pancreatic damage and whether inhibition of this factor can prevent the progression of this disorder.

Another complication of alcohol abuse is cardiovascular disorders including abnormal heart rhythm, cardiomyopathy and even sudden cardiac death $[105,106]$. It has been shown that miRNAs are involved in many pathological processes in the myocardium, such as fibrosis, apoptosis, oxidative stress and hypertrophy $[107,108]$. In patients with alcoholic cardiomyopathy, characteristic miRNA changes in the form of increased (miR-138, miR-548-3p, miR-506, miR-512-5p, miR-4262) and decreased (miR-30a) expression have been observed. Jing et al. found miR-138 to be a useful biomarker for the early diagnosis of alcoholic cardiomyopathy [109].

Chronic alcohol abuse also has toxic effects on bone marrow cells leading to inhibition of erythropoiesis and normal bone marrow function. Macrocytosis and osteoporosis have been repeatedly reported in patients with AUD [110, 111]. Ethanol can inhibit osteoblastogenesis and also increase bone mass degradation disrupting normal homeostasis [112,113]. The role of miRNAs in bone marrow depression in the course of alcohol dependence has not yet been well studied. It has been suggested that some miRNAs (miR-21, miR-29a, miR-29b, miR-31, miR-124, miR-133a, miR-223, miR-378, miR-503) may play an important role in osteoclast differentiation and maturation and cym zapaleniem okrężnicy indukowanym przez alkohol [100].

Nadmierne spożywanie alkoholu może również doprowadzić do zapalenia i zwłóknienia trzustki [101, 102]. W badaniu przeprowadzonym na modelu zwierzęcym wykazano, że przewlekłe podawanie etanolu wywoływało zmiany $\mathrm{w}$ ekspresji poszczególnych miRNA w trzustce. Obserwowano zarówno wzrost (miR-21, miR-199a-3p, miR-211), jak i obniżenie (miR-148a i miR-802) ekspresji miRNA [102]. Istnieją dane, które wskazują na to, że miR-21 jest cząsteczką uczestniczącą $\mathrm{w}$ regulacji poziomu czynnika wzrostu tkanki łącznej (CTGF) w przebiegu przewlekłego zapalenia trzustki [103]. Zarówno nadekspresja miR-21, jak i podwyższony poziom czynnika wzrostu tkanki łącznej biorą udział w aktywacji komórek gwiaździstych (PSC) w alkoholowym zapaleniu czy zwłóknieniu trzustki [103, 104]. Niewątpliwie potrzebne są dalsze badania $\mathrm{w}$ celu wyjaśnienia, czy miR-21 jest użytecznym biomarkerem określającym stopień zaawansowania uszkodzenia trzustki oraz czy inhibicja tego czynnika może zapobiec progresji tego zaburzenia.

Kolejnym powikłaniem nadużywania alkoholu są zaburzenia kardiologiczne obejmujące zaburzenia rytmu serca, kardiomiopatię, a nawet nagłą śmierć sercową $[105,106]$. Wykazano, że miRNA biorą udział $\mathrm{w}$ wielu procesach patologicznych zachodzących w mięśniu sercowym, takich jak zwłóknienie, apoptoza, stres oksydacyjny czy hipertrofia [107, 108]. U pacjentów z alkoholową kardiomiopatią zaobserwowano charakterystyczne zmiany miRNA w postaci wzrostu (miR-138, miR-548-3p, miR-506, miR-512-5p, , miR-4262) i obniżenia (miR-30a) ekspresji. Jing i wsp. uznali miR-138 za biomarker użyteczny we wczesnej diagnostyce kardiomiopatii alkoholowej [109].

Przewlekłe nadużywanie alkoholu działa toksycznie również na komórki szpiku kostnego, co prowadzi do zahamowania erytropoezy i prawidłowej czynności szpiku kostnego. Wielokrotnie zgłaszano makrocytozę i osteoporozę u pacjentów z AUD [110, 111]. Etanol może hamować osteoblastogenezę, a także zwiększać degradację masy kostnej, zaburzając prawidłową homeostazę [112, 113]. Rola miRNA w depresji szpiku kostnego w przebiegu uzależnienia od alkoholu nie została jeszcze dobrze zbadana. Sugeruje się, że niektóre miRNA (miR-21, miR-29a, miR-29b, miR-31, miR-124, miR-133a, miR-223, miR-378, miR-503) 
bone resorption [114]. Their dysregulation may inhibit these processes.

When analysing the results of molecular studies, it should be remembered that different populations are often characterised by a specific genetic profile resulting from specific evolutionary and demographic processes. Therefore the frequency of a given genetic variant occurence, potentially characteristic of a given disease entity, may differ from the frequency observed in another population. Among alcohol-dependent patients, miR-451a, miR-100-5p, miR-3613-5p and miR-7704 were found to be specific to African-American populations, whereas miR-126-3p and miR-1273h-5p were found to be specific to Euro-American populations [83]. It is therefore important that the miRNA biomarker profile is appropriately defined for the population under study. A summary of studies on miRNA expression profile in alcohol use disorders is presented in the Annex.

\section{MicroRNAs as new therapeutic opportunities}

With the discovery of miRNA molecules and the knowledge of their function in various biological pathways, new possibilities for the treatment of many disorders have emerged. This initiated an intensive research progress on the development of a new class of medicines using these molecules. MicroRNAs have emerged as potential targets the selective modulation of which can alter the phenotype and course of disease. The results of the first experimental studies based on gene expression modelling using miRNAs [63] are promising. For miRNAs the expression of which is down-regulated in the disease state, the introduction of a specific miRNA into the relevant tissue can induce a beneficial therapeutic effect by restoring the normal regulation of target genes within the cell. Increased expression is achieved by using miRNA precursors or oligonucleotide mimics so-called artificial miRNAs (amiRNA) and synthetic miRNAs introduced into cells using specially designed vectors [115, 116]. In the case of the miRNAs with an increased expression in the disease state, a therapeutic effect based on the restoration of normal regulation of target genes can be induced by inhibiting the function of specific miRNAs [117]. For this purpose, miRNA antagonists or antisense miRNAs so-called antagomirs are used. Antagomirs are oligonucleotides complementary to specific mogą odgrywać istotną rolę w różnicowaniu i dojrzewaniu osteoklastów oraz resorpcji kości [114]. Ich dysregulacja może hamować te procesy.

Analizując wyniki badań molekularnych, należy pamiętać, że różne populacje często charakteryzują się swoistym profilem genetycznym. Wynika on z zachodzących procesów ewolucyjnych i demograficznych. Dlatego też częstość występowania danego wariantu genetycznego, potencjalnie charakterystycznego dla danej jednostki chorobowej, może różnić się od częstości obserwowanej w innej populacji. Wśród pacjentów uzależnionych od alkoholu miR-451a, miR-100-5p, miR-3613-5p oraz miR-7704 okazały się specyficzne dla populacji afroamerykańskiej, podczas gdy miR-126-3p i miR-1273h-5p - dla euroamerykańskiej [83]. Ważne jest zatem, aby profil biomarkerów miRNA był odpowiednio określony dla badanej populacji. Zestawienie badań dotyczących profilu ekspresji miRNA w zaburzeniach związanych $\mathrm{z}$ używaniem alkoholu przedstawiono w Aneksie.

\section{MikroRNA jako nowe możliwości terapeutyczne}

Wraz z odkryciem cząsteczek miRNA i poznaniem ich funkcji w różnych szlakach biologicznych pojawiły się nowe możliwości terapii wielu zaburzeń. Zainicjowało to intensywny rozwój badań nad opracowaniem nowej klasy terapeutyków z wykorzystaniem tych cząsteczek. MikroRNA okazały się potencjalnymi celami, których selektywna modulacja może zmienić fenotyp i przebieg choroby. Obiecująco przedstawiają się wyniki pierwszych badań doświadczalnych opartych na modelowaniu ekspresji genów z wykorzystaniem miRNA [63]. $\mathrm{W}$ przypadku miRNA, których ekspresja $\mathrm{w}$ stanie chorobowym ulega obniżeniu, wprowadzenie konkretnego miRNA do właściwej tkanki może wywołać korzystny efekt terapeutyczny przez przywrócenie prawidłowej regulacji docelowych genów wewnątrz komórki. Wzrost ekspresji osiąga się przez wykorzystanie prekursorów miRNA lub oligonukleotydów naśladujących, tzw. sztucznych miRNA (amiRNA) oraz syntetycznych miRNA, wprowadzonych do komórek za pomocą specjalnie zaprojektowanych wektorów $[115,116]$. W przypadku miRNA, których ekspresja w stanie chorobowym ulega zwiększeniu, efekt terapeutyczny oparty na przywróceniu prawidłowej regulacji genów docelowych można wywołać, hamując funkcję konkretnych miRNA [117]. W tym celu wykorzystuje się antagonistów miRNA lub antysensowne miRNA, tzw. antagomiry. Antagomiry są oligonukleotydami komplementarnymi w stosunku 
mature miRNA molecules causing their inactivation [118]. Therefore insight into the miRNA profile specific to a particular disease entity enables the development of a unique therapeutic approach.

Artificial miRNAs have already been used to treat neurodegenerative and mental diseases [119]. Most of the studies targeting new therapeutic opportunities for the use of miRNAs in alcohol use disorders concern ALD. In this disorder, both increased and decreased expression of particular miRNAs are observed [91, 99]. In alcohol-dependent individuals, decreased level of neutrophil miR-223, the most abundant miRNA in granulocyte neutrophils, are observed. It appears that miR-223 plays a significant role in regulating neutrophil function by inhibiting IL-6 expression and the generation of reactive oxygen species (ROS), as well as the expression of p47phox oxidase, important in the oxidative stress pathway. The infiltration of neutrophil granulocytes, characteristic of alcoholic liver disease, leads to inflammation and fibrosis of the organ via ROS, proteases and pro-inflammatory mediators. Down-regulation of neutrophilic miR-223 level may exacerbate alcohol-activated neutrophilic granulocyte activation and associated liver damage. Therefore miR-23 modulation has become the target of a new therapeutic strategy in ALD. Administration of a lentivirus introducing the pre-miR-223 sequence helped to reduce alcohol-induced liver damage [120].

Not only direct modulation of miRNAs can have a therapeutic effect. Studies have shown that both melatonin and intestinal probiotics prevent ALD by indirect regulation of miRNAs $[119,121]$. The probiotic Lactobacillus rhamnosus GG down-regulates miR-122a level, which increases occludin expression. This restores intestinal integrity and protects against ALD [121]. Miravirsen, a miR-122 inhibitor used in the treatment of chronic hepatitis $\mathrm{C}$, has been proposed as a potential therapeutic strategy in ALD [122].

In alcohol-induced osteopenia, miR-136-3p is a potential therapeutic target. Reduced miRNA-136-3p level observed after alcohol administration was associated with inhibition of vascularisation and osteogenic differentiation in human umbilical vein endothelial cells (HUVECs) and bone mesenchymal stem cells (BMSCs). A study do określonych, dojrzałych cząsteczek miRNA, powodującymi ich inaktywację [118]. W związku z tym znajomość profilu miRNA, charakterystycznego dla danej jednostki chorobowej, umożliwia opracowanie unikalnego podejścia terapeutycznego.

Sztuczne miRNA wykorzystano już w leczeniu chorób neurodegeneracyjnych i psychicznych [119]. Większość badań ukierunkowanych na nowe możliwości terapeutyczne wykorzystania miRNA w zaburzeniach związanych z używaniem alkoholu dotyczy ALD. W tym zaburzeniu obserwuje się zarówno wzrost, jak i obniżenie ekspresji poszczególnych miRNA [91, 99]. U osób uzależnionych od alkoholu stwierdza się obniżony poziom neutrofilowego miR-223, najliczniej występującego miRNA w granulocytach obojętnochłonnych. Okazuje się, że miR-223 odgrywa znaczącą rolę $\mathrm{w}$ regulacji funkcji neutrofili przez hamowanie ekspresji IL-6 i generowania reaktywnych form tlenu (ROS), a także ekspresji oksydazy p47phox, istotnych w szlaku stresu oksydacyjnego. Naciek granulocytów obojętnochłonnych, charakterystyczny dla alkoholowej choroby wątroby, prowadzi do zapalenia oraz zwłóknienia narządu za pośrednictwem ROS, proteaz i mediatorów prozapalnych. Obniżenie poziomu neutrofilowego miR-223 może nasilić aktywowaną przez alkohol aktywację granulocytów obojętnochłonnych i związane z tym uszkodzenie wątroby. W związku z tym modulacja miR-23 stała się celem nowej strategii terapeutycznej w ALD. Podanie lentiwirusa wprowadzającego sekwencję pre-miR-223 przyczyniło się do zmniejszenia uszkodzenia wątroby wywołanego przez alkohol [120].

Nie tylko bezpośrednia modulacja miRNA może mieć efekt terapeutyczny. Badania wykazały, że zarówno melatonina, jak i probiotyki jelitowe zapobiegają ALD przez pośrednią regulację miRNA $[119,121]$. Probiotyk Lactobacillus rhamnosus GG obniża poziom miR-122a, co wpływa na zwiększenie ekspresji okludyny. Przywraca to integralność jelit i chroni przed ALD [121]. Stosowany w leczeniu przewlekłego zapalenia wątroby typu C Miravirsen, będący inhibitorem miR-122, został zaproponowany jako potencjalna strategia terapeutyczna w ALD [122].

W osteopenii indukowanej przez alkohol potencjalnym celem terapeutycznym jest miR-136-3p. Obniżony poziom miRNA-136-3p, obserwowany po podaniu alkoholu, związany był $\mathrm{z}$ hamowaniem unaczynienia i różnicowania osteogennego w komórkach śródbłonka ludzkiej żyły pępowinowej (HUVECs) oraz w mezenchymalnych komórkach macierzystych kości (BMSCs). Badanie przeprowadzone na modelu zwierzęcym potwierdziło 
in an animal model confirmed the potential therapeutic effect of this molecule. MicroRNA-136-3p Agomir alleviated alcohol-induced osteopenia, with concomitant restoration of bone mass and vessel formation. Modulation of miR-136-3p expression may reduce the harmful effects of ethanol on the skeletal system [123].

Most et al. demonstrated a reduction in alcohol intake in mice after treatment with antagomiR-411. AntagomiR-411 reduced the level of miR-411. In addition, it increased the neuronal expression of the AMPA- 2 receptor, important in the neurobiology of dependence, which is likely a target of miR-411. Interestingly, antagomiR-411 reduced alcohol intake only in alcohol-dependent mice. In animals that had not previously been exposed to alcohol, antagomiR-411 had no effect on the amount of alcohol consumed. This suggests that antagomiR-411 may have neuroadaptive effects in alcohol dependence and reduce excessive consumption [124]. Other researchers, Bahi and Dreyer showed that miR-124a, the direct target of which is the BDNF gene, can regulate the motivation to consume alcohol. LV-siR124a, a miR124a inhibitor, introduced via a specially designed virus into the dorsolateral striatum, reduced voluntary alcohol consumption in rats [15].

Another therapeutic target in AUD may be the neurokinin 1 gene receptor $(N K 1 R)$, involved in the reward system. Mice genetically modified for NK1R deficiency showed significantly lower voluntary alcohol consumption compared to wildtype strain mice with normal NK1R expression. Hence, amiNK1R, which is an NK1R antagonist, shows therapeutic potential in alcohol abuse disorders [125]. It may affect the reduction of alcohol consumption by silencing the expression of the gene $N K 1 R$ in the hippocampus. In a clinical trial, blockade of NK1R receptors reduced alcohol craving and improved mood among alcohol-dependent individuals with high anxiety level undergoing recent detoxification. These results suggest that synthetic miRNAs that suppress NK1R may provide a therapeutic target for alcohol dependence [126].

The prospect of using miRNAs in AUD therapy is increasingly realistic. Rapidly developing molecular biology techniques and numerous ongoing studies in this area may contribute to the development of new therapeutic strategies. potencjalne działanie terapeutyczne tej cząsteczki. MikroRNA-136-3p Agomir łagodził osteopenię wywołaną przez alkohol, przy równoczesnym przywróceniu masy kostnej i tworzeniu naczyń. Modulacja ekspresji miR-136-3p może zmniejszyć szkodliwe działanie etanolu na układ kostny [123].

Most i wsp. wykazali redukcję spożycia alkoholu u myszy po zastosowaniu antagomiR-411. AntagomiR-411 zmniejszył poziom miR-411. Ponadto zwiększył neuronalną ekspresję receptora AMPA-2, istotnego $\mathrm{w}$ neurobiologii uzależnienia, który prawdopodobnie jest celem działania miR-411. Co ciekawe, antagomiR-411 zmniejszał spożycie alkoholu tylko u myszy uzależnionych od alkoholu. U zwierząt, które wcześniej nie były poddane ekspozycji na alkohol, antagomiR-411 nie wpływał na ilość konsumowanego alkoholu. Sugeruje to, że antagomiR-411 może mieć działanie neuroadaptacyjne w uzależnieniu od alkoholu oraz redukować nadmierną konsumpcję [124]. Inni badacze, Bahi i Dreyer, wykazali, że miR-124a, której bezpośrednim celem jest gen $B D N F$, może regulować motywację do spożywania alkoholu. LV-siR124a, hamujący wzrost miR-124a, wprowadzony za pośrednictwem specjalnie zaprojektowanego wirusa do grzbietowo-bocznej części prążkowia, ograniczył dobrowolne spożywanie alkoholu u szczurów [15].

Kolejnym celem terapeutycznym w AUD może być gen receptora neurokininy (NK1R) zaangażowanego w układ nagrody. U myszy zmodyfikowanych genetycznie pod kątem niedoboru NK1R obserwowano znacznie mniejszą dobrowolną konsumpcję alkoholu $\mathrm{w}$ porównaniu $\mathrm{z}$ myszami szczepu dzikiego mających prawidłową ekspresję NK1R. Dlatego amiNK1R, będący antagonistą NK1R, wykazuje potencjał terapeutyczny w zaburzeniach związanych $\mathrm{z}$ nadużywaniem alkoholu [125]. Może wpłynąć na redukcję konsumpcji alkoholu przez wyciszenie ekspresji genu NK1R $\mathrm{w}$ hipokampie. W badaniu klinicznym blokada receptorów NK1R zmniejszała pragnienie alkoholu oraz poprawiała samopoczucie wśród osób uzależnionych od alkoholu $\mathrm{z}$ wysokim poziomem lęku poddanych niedawno detoksykacji. Wyniki te sugerują, że syntetyczne miRNA tłumiące NK1R mogą stanowić cel terapeutyczny w przypadku uzależnienia od alkoholu [126].

Perspektywa wykorzystania miRNA w terapii AUD jest coraz bardziej realna. Dynamicznie rozwijające się techniki biologii molekularnej oraz licznie prowadzone badania $\mathrm{w}$ tym obszarze moga przyczynić się do opracowania nowych strategii terapeutycznych. 


\section{- CONCLUSIONS}

Regulatory miRNA molecules act as novel molecular markers associated with the pathogenesis, course and prognosis of alcohol use disorders. Profiling the expression of miRNAs specific for this disorder may provide information useful for diagnosis and selection of individual therapy already in the early stages of the disease.

Analysis of the available literature suggests that circulating miRNAs may be sensitive and specific biomarkers reflecting alcohol-induced organ damage as well as brain processes. An additional advantage is that c-miRNAs can be assessed in peripheral blood or saliva, which are readily available diagnostic materials that can be collected in a minimally invasive manner. As opposed to protein biomarkers, the use of miRNAs derived from blood or saliva would allow an earlier and more sensitive diagnosis of a wide spectrum of alcohol-induced multi-organ damage. The arguments cited in this paper support the use of c-miRNA in diagnostic and clinical practice. However, it requires further research to precisely define the miRNA expression profile characteristic for the onset and course of alcohol use disorder (AUD) and to standardise research procedures.

In addition to the potential for diagnostic applications, miRNAs represent a new and promising target for the development of therapeutic strategies that may prove useful in the selection of individual treatment. Perhaps in the future, it will be possible to determine individual sensitivity to alcohol on the basis of differences in miRNA expression and to identify individuals at particular risk of exposure, dependence or damage to specific organs.

\section{WNIOSKI}

Regulacyjne cząsteczki miRNA pełnią rolę nowych markerów molekularnych związanych $\mathrm{z}$ patogenezą, przebiegiem i rokowaniem $\mathrm{w}$ zaburzeniach związanych z używaniem alkoholu. Profilowanie ekspresji miRNA charakterystycznej dla tego zaburzenia może dostarczyć informacji przydatnych w diagnostyce i wyborze indywidualnej terapii już we wczesnych stadiach choroby.

$\mathrm{Z}$ analizy dostępnej literatury wynika, że krążące miRNA mogą stanowić czułe i swoiste biomarkery odzwierciedlające indukowane przez alkohol uszkodzenie narządów, a także procesy zachodzące w mózgu. Dodatkową zaletą jest możliwość oceny c-miRNA we krwi obwodowej lub ślinie, które stanowią łatwo dostępny materiał diagnostyczny, możliwy do pobrania w sposób mało inwazyjny. Wykorzystanie miRNA pochodzących $\mathrm{z}$ krwi lub śliny pozwoliłoby $-\mathrm{w}$ porównaniu $\mathrm{z}$ biomarkerami białkowymi - na wcześniejszą i czulszą diagnostykę szerokiego spektrum uszkodzeń wielonarządowych wywołanych przez alkohol. Przytoczone $\mathrm{w}$ niniejszej pracy argumenty przemawiają za wykorzystaniem c-miRNA w praktyce diagnostyczno-klinicznej. Wymaga to jednak dalszych badań w celu dokładnego określenia charakterystycznego dla wystąpienia i przebiegu zaburzeń związanych z używaniem alkoholu (AUD) profilu ekspresji miRNA oraz standaryzacji procedur badawczych.

Oprócz możliwości zastosowań diagnostycznych, miRNA stanowią nowy i obiecujący cel rozwoju strategii terapeutycznych, które mogą okazać się użyteczne w wyborze indywidualnego leczenia. Być może w przyszłości na podstawie różnic w ekspresji miRNA będzie można określić indywidualną wrażliwość na alkohol i identyfikować osoby szczególnie narażone na ekspozycję, uzależnienie czy uszkodzenie określonych narządów.

Conflict of interest/Konflikt interesów

None declared./Nie występuje.

Financial support/Finansowanie

None declared./Nie zadeklarowano.

\section{Ethics/Etyka}

The work described in this article has been carried out in accordance with the Code of Ethics of the World Medical Association (Declaration of Helsinki) on medical research 
involving human subjects, Uniform Requirements for manuscripts submitted to biomedical journals and the ethical principles defined in the Farmington Consensus of 1997.

Treści przedstawione w pracy są zgodne z zasadami Deklaracji Helsińskiej odnoszącymi się do badań $\mathrm{z}$ udziałem ludzi, ujednoliconymi wymaganiami dla czasopism biomedycznych oraz z zasadami etycznymi określonymi w Porozumieniu z Farmington w 1997 roku.

\section{References/Piśmiennictwo}

1. World Health Organization, Global status report on alcohol and health. 2018. https://apps. who.int/iris/bitstream/handle/10665/274603/9789241565639-eng.pdf(Accessed: 07.03.2020).

2. Państwowa Agencja Rozwiązywania Problemów Alkoholowych, Statystyki. 2014. http:// www.parpa.pl/index.php/33-analizy-badania-raporty/132-statystyki (Accessed: 07.03.2020).

3. Necsulea A, Kaessmann H. Evolutionary dynamics of coding and non-coding transcriptomes. Nat Rev Genet 2014; 15(11): 734-48.

4. Alexander RP, Fang G, Rozowsky J, Snyder M, Gerstein MB. Annotating non-coding regions of the genome. Nat Rev Genet 2010; 11(8): 559-71.

5. Ha TY. MicroRNAs in Human Diseases: From Autoimmune Diseases to Skin, Psychiatric and Neurodegenerative Diseases. Immune Netw 2011; 11(5): 227-44.

6. Condorelli G, Latronico MV, Cavarretta E. microRNAs in cardiovascular diseases: current knowledge and the road ahead. J Am Coll Cardiol 2014; 63(21): 2177-87.

7. Sun P, Shen Y, Gong JM, Zhou LL, Sheng JH, Duan FJ. A New MicroRNA Expression Signature for Cervical Cancer. Int J Gynecol Cancer 2017; 27: 339-43.

8. Luoni A, Riva MA. MicroRNAs and psychiatric disorders: From aetiology to treatment. Pharmacol Ther 2016; 167: 13-27.

9. Shan H, Zhang Y, Lu Y, Zhang Y, Pan Z, Cai B, et al. Downregulation of miR-133 and miR-590 contributes to nicotine-induced atrial remodelling in canines. Cardiovasc Res 2009; 83(3): 465-72.

10. Wu Q, Zhang L, Law PY, Wei LN, Loh HH. Long-term morphine treatment decreases the association of mu-opioid receptor (MOR1) mRNA with polysomes through miRNA23b. Mol Pharmacol 2009; 75(4): 744-50.

11. Chandrasekar V, Dreyer JL. microRNAs miR-124, let-7d and miR-181a regulate cocaine-induced plasticity. Mol Cell Neurosci 2009; 42(4): 350-62.

12. Pietrzykowski AZ, Friesen RM, Martin GE, Puig SI, Nowak CL, Wynne PM, et al. Posttranscriptional regulation of BK channel splice variant stability by miR-9 underlies neuroadaptation to alcohol. Neuron 2008; 59(2): 274-87.

13. Sathyan P, Golden HB, Miranda RC. Competing interactions between micro-RNAs determine neural progenitor survival and proliferation after ethanol exposure: evidence from an ex vivo model of the fetal cerebral cortical neuroepithelium. J Neurosci 2007; 27(32): 8546-57.

14. Lewohl JM, Nunez YO, Dodd PR, Tiwari GR, Harris RA, Mayfield RD. Up-regulation of microRNAs in brain of human alcoholics. Alcohol Clin Exp Res 2011; 35(11): 1928-37.

15. Bahi A, Dreyer JL. Striatal modulation of BDNF expression using microRNA124a-expressing lentiviral vectors impairs ethanol-induced conditioned-place preference and voluntary alcohol consumption. Eur J Neurosci 2013; 38(2): 2328-37.

16. Lee RC, Feinbaum RL, Ambros V. The C. elegans heterochronic gene lin-4 encodes small RNAs with antisense complementarity to lin-14. Cell 1993; 75: 843-54.

17. Tomaselli S, Panera N, Gallo A, Alisi A. Circulating miRNA profiling to identify biomarkers of dysmetabolism. Biomark Med 2012; 6(6): 729-42.

18. Iorio MV, Croce CM. MicroRNA dysregulation in cancer: diagnostics, monitoring and therapeutics. A comprehensive review. EMBO Mol Med 2012; 4(3): 143-59.

19. O'Carroll D, Schaefer A. General principals of miRNA biogenesis and regulation in the brain. Neuropsychopharmacol 2013; 38(1): 39-54.

20. Ameres SL, Zamore PD. Diversifying microRNA sequence and function. Nat Rev Mol Cell Biol 2013; 14(8): 475-88. 
21. Yang N, Ekanem NR, Sakyi CA, Ray SD. Hepatocellular carcinoma and microRNA: new perspectives on therapeutics and diagnostics. Adv Drug Deliv Rev 2015; 81: 62-74.

22. Pleister A, Selemon H, Elton SM, Elton TS. Circulating miRNAs: novel biomarkers of acute coronary syndrome? Biomark Med 2013; 7(2): 287-305.

23. Londin E, Loher P, Telonis AG, Quann K, Clark P, Jing Y, et al. Analysis of 13 cell types reveals evidence for the expression of numerous novel primate- and tissue-specific microRNAs. Proc Natl Acad Sci USA 2015; 112(10): E1106-15.

24. Krol J, Loedige I, Filipowicz W. The widespread regulation of microRNA biogenesis, function and decay. Nat Rev Genet 2010; 11(9): 597-610.

25. Bartel DP. MicroRNAs: target recognition and regulatory functions. Cell 2009; 136(2): 215-33.

26. Vasudevan S, Tong Y, Steitz JA. Switching from repression to activation: microRNAs can up-regulate translation. Science 2007; 318(5858): 1931-4.

27. Miska EA, Alvarez-Saavedra E, Townsend M, Yoshii A, Sestan N, Rakic P, et al. Microarray analysis of microRNA expression in the developing mammalian brain. Genome Biol 2004; 5(9): R68.

28. Mendell JT, Olson EN. MicroRNAs in stress signaling and human disease. Cell 2012; 148(6): 1172-87.

29. Cheng LC, Pastrana E, Tavazoie M, Doetsch F. miR-124 regulates adult neurogenesis in the subventricular zone stem cell niche. Nat Neurosci 2009; 12(4): 399-408.

30. Schaefer A, O'Carroll D, Tan CL, Hillman D, Sugimori M, Llinas R, et al. Cerebellar neurodegeneration in the absence of microRNAs. J Exp Med 2007; 204(7): 1553-8.

31. Siegel G, Obernosterer G, Fiore R, Oehmen M, Bicker S, Christensen M, et al. A functional screen implicates microRNA-138-dependent regulation of the depalmitoylation enzyme APT1 in dendritic spine morphogenesis. Nat Cell Biol 2009; 11(6): 705-16.

32. Sato F, Tsuchiya S, Meltzer SJ, Shimizu K. MicroRNAs and epigenetics. Febs Journal 2011; 278(10): 1598-609.

33. Im HI, Kenny PJ. MicroRNAs in neuronal function and dysfunction. Trends Neurosci 2012; 35(5): 325-34.

34. Gilpin NW, Koob GF. Neurobiology of alcohol dependence: focus on motivational mechanisms. Alcohol Res Health 2008; 31(3): 185-95.

35. Martinetz S. MicroRNA's impact on neurotransmitter and neuropeptide systems: small but mighty mediators of anxiety. Pflugers Arch 2016; 468(6): 1061-9.

36. Li J, Li J, Liu X, Qin S, Guan Y, Liu Y, et al. MicroRNA expression profile and functional analysis reveal that miR-382 is a critical novel gene of alcohol addiction. EMBO Mol Med 2013; 5(9): 1402-14.

37. Xiong M, Li J, Ye JH, Zhang C. Upregulation of DeltaFosB by propofol in rat nucleus accumbens. Anesth Analg 2011; 113(2): 259-64.

38. Abrahao KP, Quadros IM, Souza-Formigoni ML. Nucleus accumbens dopamine D(1) receptors regulate the expression of ethanol-induced behavioural sensitization. Int J Neuropsychopharmacol 2011; 14(2): 175-85.

39. Corbel C, Hernandez I, Wu B, Kosik KS. Developmental attenuation of N-methyl-D-aspartate receptor subunit expression by microRNAs. Neural Dev 2015; 10: 20.

40. Harraz MM, Eacker SM, Wang X, Dawson TM, Dawson VL. MicroRNA-223 is neuroprotective by targeting glutamate receptors. Proc Natl Acad Sci USA 2012; 109(46): 18962-7.

41. Ho VM, Dallalzadeh LO, Karathanasis N, Keles MF, Vangala S, Grogan T, et al. GluA2 mRNA distribution and regulation by miR-124 in hippocampal neurons. Mol Cell Neurosci 2014; 61: 1-12.

42. Saba R, Storchel PH, Aksoy-Aksel A, Kepura F, Lippi G, Plant TD, et al. Dopamine-regulated microRNA MiR-181a controls GluA2 surface expression in hippocampal neurons. Mol Cell Biol 2012; 32(3): 619-32.

43. Moya PR, Wendland JR, Salemme J, Fried RL, Murphy DL. miR-15a and miR-16 regulate serotonin transporter expression in human placental and rat brain raphe cells. Int J Neuropsychopharmacol 2013; 16(3): 621-9. 
44. Issler O, Haramati S, Paul ED, Maeno H, Navon I, Zwang R, et al. MicroRNA 135 is essential for chronic stress resiliency, antidepressant efficacy, and intact serotonergic activity. Neuron 2014; 83(2): 344-60.

45. Baudry A, Mouillet-Richard S, Schneider B, Launay JM, Kellermann O. miR-16 targets the serotonin transporter: a new facet for adaptive responses to antidepressants. Science 2010; 329(5998): 1537-41.

46. Treistman SN, Martin GE. BK Channels: mediators and models for alcohol tolerance. Trends Neurosci 2009; 32(12): 629-37.

47. Ghezzi A, Zomeno M, Pietrzykowski AZ, Atkinson NS. Immediate-early alcohol-responsive miRNA expression in Drosophila. J Neurogenet 2016; 30(3-4): 195-204.

48. Lotharius J, Brundin P. Impaired dopamine storage resulting from alpha-synuclein mutations may contribute to the pathogenesis of Parkinson's disease. Hum Mol Genet 2002; 11(20): 2395-407.

49. Peng XM, Tehranian R, Dietrich P, Stefanis L, Perez RG. $\alpha$-Synuclein activation of protein phosphatase $2 \mathrm{~A}$ reduces tyrosine hydroxylase phosphorylation in dopaminergic cells. J Cell Sci 2005; 118(15): 3523-30.

50. Steidl JV, Gomez-Isla T, Mariash A, Ashe KH, Boland LM. Altered short-term hippocampal synaptic plasticity in mutant alpha-synuclein transgenic mice. Neuroreport 2003; 14(2): 219-23.

51. Wong YC, Krainc D. alpha-synuclein toxicity in neurodegeneration: mechanism and therapeutic strategies. Nat Med 2017; 23(2): 1-13.

52. Doxakis E. Post-transcriptional regulation of alpha-synuclein expression by mir-7 and mir-153. J Biol Chem 2010; 285(17): 12726-34.

53. Bonsch D, Greifenberg V, Bayerlein K, Biermann T, Reulbach U, Hillemacher T, et al. Alpha-synuclein protein levels are increased in alcoholic patients and are linked to craving. Alcohol Clin Exp Res 2005; 29(5): 763-5.

54. Varendi K, Kumar A, Harma MA, Andressoo JO. miR-1, miR-10b, miR-155, and miR-191 are novel regulators of BDNF. Cell Mol Life Sci 2014; 71(22): 4443-56.

55. Autry AE, Monteggia LM. Brain-derived neurotrophic factor and neuropsychiatric disorders. Pharmacol Rev 2012; 64(2): 238-58.

56. Joe KH, Kim YK, Kim TS, Roh SW, Choi SW, Kim YB, et al. Decreased plasma brain-derived neurotrophic factor levels in patients with alcohol dependence. Alcohol Clin Exp Res 2007; 31(11): 1833-8.

57. Bahi A. Hippocampal BDNF overexpression or microR124a silencing reduces anxietyand autism-like behaviors in rats. Brain Res 2017; 326: 281-90.

58. Tapocik JD, Barbier E, Flanigan M, Solomon M, Pincus A, Pilling A, et al. microRNA-206 in rat medial prefrontal cortex regulates BDNF expression and alcohol drinking. $J \mathrm{Neu}$ rosci 2014; 34(13): 4581-8.

59. Darcq E, Warnault V, Phamluong K, Besserer GM, Liu F, Ron D. MicroRNA-30a-5p in the prefrontal cortex controls the transition from moderate to excessive alcohol consumption. Mol Psychiatry 2015; 20(10): 1219-31.

60. Sinha R. Stress and addiction: a dynamic interplay of genes, environment, and drug intake. Biol Psychiatry 2009; 66(2): 100-1.

61. Beech RD, Leffert JJ, Lin A, Hong KA, Hansen J, Umlauf S, et al. Stress-related alcohol consumption in heavy drinkers correlates with expression of miR-10a, miR-21, and components of the TAR-RNA-binding protein-associated complex. Alcohol Clin Exp Res 2014; 38(11): 2743-53.

62. Califf RM. Biomarker definitions and their applications. Exp Biol Med (Maywood) 2018; 243(3): 213-21.

63. Bertoli G, Cava C, Castiglioni I. MicroRNAs: New Biomarkers for Diagnosis, Prognosis, Therapy Prediction and Therapeutic Tools for Breast Cancer. Theranostics 2015; 5(10): 1122-43.

64. Turchinovich A, Weiz L, Langheinz A, Burwinkel B. Characterization of extracellular circulating microRNA. Nucleic Acids Res 2011; 39(16): 7223-33.

65. Sasso L, Hosamuddin H, Emanueli C. Extracellular vesicles at the cross-line between basic science and clinical needs. Microcirculation 2017; 24(1). DOI: 10.1111/micc.12333. 
66. Brase JC, Johannes M, Schlomm T, Falth M, Haese A, Steuber T, et al. Circulating miRNAs are correlated with tumor progression in prostate cancer. Int J Cancer 2011; 128(3): 608-16.

67. Pigati L, Yaddanapudi SC, Iyengar R, Kim DJ, Hearn SA, Danforth D, et al. Selective release of microRNA species from normal and malignant mammary epithelial cells. PLoS One 2010; 5(10): e13515.

68. Etheridge A, Lee I, Hood L, Galas D, Wang K. Extracellular microRNA: a new source of biomarkers. Mutat Res 2011; 717(1-2): 85-90.

69. Arroyo JD, Chevillet JR, Kroh EM, Ruf IK, Pritchard CC, Gibson DF, et al. Argonaute2 complexes carry a population of circulating microRNAs independent of vesicles in human plasma. Proc Natl Acad Sci USA 2011; 108(12): 5003-8.

70. Mall C, Rocke DM, Durbin-Johnson B, Weiss RH. Stability of miRNA in human urine supports its biomarker potential. Biomark Med 2013; 7(4): 623-31.

71. Mitchell PS, Parkin RK, Kroh EM, Fritz BR, Wyman SK, Pogosova-Agadjanyan EL, et al. Circulating microRNAs as stable blood-based markers for cancer detection. Proc Natl Acad Sci USA 2008; 105(30): 10513-8.

72. Pal MK, Jaiswar SP, Dwivedi VN, Tripathi AK, Dwivedi A, Sankhwar P. MicroRNA: a new and promising potential biomarker for diagnosis and prognosis of ovarian cancer. Cancer Biol Med 2015; 12(4): 328-41.

73. Madhavan B, Yue S, Galli U, Rana S, Gross W, Muller M, et al. Combined evaluation of a panel of protein and miRNA serum-exosome biomarkers for pancreatic cancer diagnosis increases sensitivity and specificity. Int J Cancer 2015; 136(11): 2616-27.

74. Yu HW, Cho WC. The role of microRNAs in toxicology. Arch Toxicol 2015; 89(3): $319-25$.

75. Liew CC, Ma J, Tang HC, Zheng R, Dempsey AA. The peripheral blood transcriptome dynamically reflects system wide biology: a potential diagnostic tool. J Lab Clin Med 2006; 147(3): 126-32.

76. Jin XF, Wu N, Wang L, Li J. Circulating microRNAs: a novel class of potential biomarkers for diagnosing and prognosing central nervous system diseases. Cell Mol Neurobiol 2013; 33(5): 601-13.

77. Danborg PB, Simonsen AH, Waldemar G, Heegaard NH. The potential of microRNAs as biofluid markers of neurodegenerative diseases--a systematic review. Biomarkers 2014; 19(4): 259-68.

78. Polakovicova M, Musil P, Laczo E, Hamar D, Kyselovic J. Circulating MicroRNAs as Potential Biomarkers of Exercise Response. Int J Mol Sci 2016; 17(10): 1553.

79. Ignacio C, Hicks SD, Burke P, Lewis L, Szombathyne-Meszaros Z, Middleton FA. Alterations in serum microRNA in humans with alcohol use disorders impact cell proliferation and cell death pathways and predict structural and functional changes in brain. $B M C$ Neurosci 2015; 16: 55.

80. Eacker SM, Dawson TM, Dawson VL. The interplay of microRNA and neuronal activity in health and disease. Front Cell Neurosci 2013; 7: 136.

81. Lovinger DM, Roberto M. Synaptic effects induced by alcohol. Curr Top Behav Neurosci 2013; 13: 31-86.

82. Tu Y, Kroener S, Abernathy K, Lapish C, Seamans J, Chandler LJ, et al. Ethanol inhibits persistent activity in prefrontal cortical neurons. J Neurosci 2007; 27(17): 4765-75.

83. Rosato A, Chen X, Tanaka Y, Farrer L, Kranzler H, Nunez Y, et al. Salivary microRNAs identified by small RNA sequencing and machine learning as potential biomarkers of alcohol dependence. Epigenomics 2019; 11.

84. Miranda RC, Pietrzykowski AZ, Tang Y, Sathyan P, Mayfield D, Keshavarzian A, et al. MicroRNAs: master regulators of ethanol abuse and toxicity? Alcohol Clin Exp Res 2010; 34(4): 575-87.

85. Natarajan SK, Pachunka JM, Mott JL. Role of microRNAs in Alcohol-Induced Multi-Organ Injury. Biomolecules 2015; 5(4): 3309-38.

86. McDaniel K, Herrera L, Zhou T, Francis H, Han Y, Levine P, et al. The functional role of microRNAs in alcoholic liver injury. J Cell Mol Med 2014; 18(2): 197-207. 
87. Bala S, Marcos M, Kodys K, Csak T, Catalano D, Mandrekar P, et al. Up-regulation of microRNA-155 in macrophages contributes to increased tumor necrosis factor $\{$ alpha\} (TNF alpha) production via increased mRNA half-life in alcoholic liver disease. $J$ Biol Chem 2011; 286(2): 1436-44.

88. Dolganiuc A, Petrasek J, Kodys K, Catalano D, Mandrekar P, Velayudham A, et al. MicroRNA expression profile in Lieber-DeCarli diet-induced alcoholic and methionine choline deficient diet-induced nonalcoholic steatohepatitis models in mice. Alcohol Clin Exp Res 2009; 33(10): 1704-10.

89. Meng F, Glaser SS, Francis H, Yang F, Han Y, Stokes A, et al. Epigenetic regulation of miR-34a expression in alcoholic liver injury. Am J Pathol 2012; 181(3): 804-17.

90. Yeligar S, Tsukamoto H, Kalra VK. Ethanol-induced expression of ET-1 and ET-BR in liver sinusoidal endothelial cells and human endothelial cells involves hypoxia-inducible factor-1alpha and microrNA-199. J Immunol 2009; 183(8): 5232-43.

91. Kong LZ, Chandimali N, Han YH, Lee DH, Kim JS, Kim SU, et al. Pathogenesis, Early Diagnosis, and Therapeutic Management of Alcoholic Liver Disease. Int J Mol Sci 2019; 20(11): 2712.

92. Chen YP, Jin X, Xiang Z, Chen SH, Li YM. Circulating MicroRNAs as potential biomarkers for alcoholic steatohepatitis. Liver Int 2013; 33(8): 1257-65.

93. Pritchard CC, Kroh E, Wood B, Arroyo JD, Dougherty KJ, Miyaji MM, et al. Blood cell origin of circulating microRNAs: a cautionary note for cancer biomarker studies. Cancer Prev Res (Phila) 2012; 5(3): 492-7.

94. Francis H, McDaniel K, Han Y, Liu X, Kennedy L, Yang F, et al. Regulation of the extrinsic apoptotic pathway by microRNA-21 in alcoholic liver injury. J Biol Chem 2014; 289(40): 27526-39.

95. Migita K, Komori A, Kozuru H, Jiuchi Y, Nakamura M, Yasunami M, et al. Circulating microRNA Profiles in Patients with Type-1 Autoimmune Hepatitis. PLoS One 2015; 10(11): e0136908.

96. Torres JL, Novo-Veleiro I, Manzanedo L, Alvela-Suarez L, Macias R, Laso FJ, et al. Role of microRNAs in alcohol-induced liver disorders and non-alcoholic fatty liver disease. World J Gastroenterol 2018; 24(36): 4104-18.

97. Momen-Heravi F, Saha B, Kodys K, Catalano D, Satishchandran A, Szabo G. Increased number of circulating exosomes and their microRNA cargos are potential novel biomarkers in alcoholic hepatitis. J Transl Med 2015; 13: 261.

98. Blaya D, Coll M, Rodrigo-Torres D, Vila-Casadesus M, Altamirano J, Llopis M, et al. Integrative microRNA profiling in alcoholic hepatitis reveals a role for microRNA-182 in liver injury and inflammation. Gut 2016; 65(9): 1535-45.

99. Li HD, Du XS, Huang HM, Chen X, Yang Y, Huang C, et al. Noncoding RNAs in alcoholic liver disease. J Cell Physiol 2019; 234 (9): 14709-20.

100. Lippai D, Bala S, Catalano D, Kodys K, Szabo G. Micro-RNA-155 deficiency prevents alcohol-induced serum endotoxin increase and small bowel inflammation in mice. Alcohol Clin Exp Res 2014; 38(8): 2217-24.

101. Apte MV, Wilson JS. Stellate cell activation in alcoholic pancreatitis. Pancreas 2003; 27(4): 316-20.

102. Cyriac J, Mahadevan P, Augustine P, Ramesh H, Koshy A. Stellate cell activation in tropical calcific pancreatitis compared to alcoholic pancreatitis, adenocarcinoma of pancreas and normal pancreas. Jop 2012; 13(4): 376-86.

103. Charrier AL, Brigstock DR. Connective tissue growth factor production by activated pancreatic stellate cells in mouse alcoholic chronic pancreatitis. Lab Invest 2010; 90(8): 1179-88.

104. Chen L, Charrier A, Zhou Y, Chen R, Yu B, Agarwal K, et al. Epigenetic regulation of connective tissue growth factor by MicroRNA-214 delivery in exosomes from mouse or human hepatic stellate cells. Hepatology 2014; 59(3): 1118-29.

105. Djousse L, Gaziano JM. Alcohol consumption and heart failure: a systematic review. Curr Atheroscler Rep 2008; 10(2): 117-20.

106. Guzzo-Merello G, Cobo-Marcos M, Gallego-Delgado M, Garcia-Pavia P. Alcoholic cardiomyopathy. World J Cardiol 2014; 6(8): 771-81. 
107. Zhang B, Zhou M, Li C, Zhou J, Li H, Zhu D, et al. MicroRNA-92a inhibition attenuates hypoxia/reoxygenation-induced myocardiocyte apoptosis by targeting Smad7. PLoS One 2014; 9(6): e100298.

108. Indolfi C, Curcio A. Stargazing microRNA maps a new miR-21 star for cardiac hypertrophy. J Clin Invest 2014; 124(5): 1896-8.

109. Jing L, Jin C, Lu Y, Huo P, Zhou L, Wang Y, et al. Investigation of microRNA expression profiles associated with human alcoholic cardiomyopathy. Cardiology 2015; 130(4): 22333.

110. Lopez-Larramona G, Lucendo AJ, Gonzalez-Delgado L. Alcoholic liver disease and changes in bone mineral density. Rev Esp Enferm Dig 2013; 105(10): 609-21.

111. Malik P, Gasser RW, Kemmler G, Moncayo R, Finkenstedt G, Kurz M, et al. Low bone mineral density and impaired bone metabolism in young alcoholic patients without liver cirrhosis: a cross-sectional study. Alcohol Clin Exp Res 2009; 33(2): 375-81.

112. Giuliani N, Girasole G, Vescovi PP, Passeri G, Pedrazzoni M. Ethanol and acetaldehyde inhibit the formation of early osteoblast progenitors in murine and human bone marrow cultures. Alcohol Clin Exp Res 1999; 23(2): 381-5.

113. Johnson TL, Gaddini G, Branscum AJ, Olson DA, Caroline-Westerlind K, Turner RT, et al. Effects of chronic heavy alcohol consumption and endurance exercise on cancellous and cortical bone microarchitecture in adult male rats. Alcohol Clin Exp Res 2014; 38(5): 1365-72.

114. Tang P, Xiong Q, Ge W, Zhang L. The role of microRNAs in osteoclasts and osteoporosis. RNA Biol 2014; 11(11): 1355-63.

115. Zeng Y, Wagner EJ, Cullen BR. Both natural and designed micro RNAs can inhibit the expression of cognate mRNAs when expressed in human cells. Mol Cell 2002; 9(6): 1327-33.

116. Zhao Z, Lin CY, Cheng K. siRNA- and miRNA-based therapeutics for liver fibrosis. Transl Res 2019; 214: 17-29.

117. Jackson A, Linsley PS. The therapeutic potential of microRNA modulation. Discov Med 2010; 9(47): 311-8.

118. Mattes J, Yang M, Foster PS. Regulation of microRNA by antagomirs: a new class of pharmacological antagonists for the specific regulation of gene function? Am J Respir Cell Mol Biol 2007; 36(1): 8-12.

119. Hutchison ER, Okun E, Mattson MP. The therapeutic potential of microRNAs in nervous system damage, degeneration, and repair. Neuromolecular Med 2009; 11(3): 153-61.

120. Li M, He Y, Zhou Z, Ramirez T, Gao Y, Gao Y, et al. MicroRNA-223 ameliorates alcoholic liver injury by inhibiting the IL-6-p47(phox)-oxidative stress pathway in neutrophils. Gut 2017; 66(4): 705-15.

121. Zhao H, Zhao C, Dong Y, Zhang M, Wang Y, Li F, et al. Inhibition of miR122a by Lactobacillus rhamnosus GG culture supernatant increases intestinal occludin expression and protects mice from alcoholic liver disease. Toxicol Lett 2015; 234(3): 194-200.

122. Janssen HL, Reesink HW, Lawitz EJ, Zeuzem S, Rodriguez-Torres M, Patel K, et al. Treatment of HCV infection by targeting microRNA. N Engl J Med 2013; 368(18): 1685-94.

123. Chen Y, Yu H, Zhu D, Liu P, Yin J, Liu D, et al. miR-136-3p targets PTEN to regulate vascularization and bone formation and ameliorates alcohol-induced osteopenia. Faseb $J$ 2020; 34(4): 5348-62.

124. Most D, Salem NA, Tiwari GR, Blednov YA, Mayfield RD, Harris RA. Silencing synaptic MicroRNA-411 reduces voluntary alcohol consumption in mice. Addict Biol 2019; 24(4): 604-16.

125. George DT, Gilman J, Hersh J, Thorsell A, Herion D, Geyer C, et al. Neurokinin 1 receptor antagonism as a possible therapy for alcoholism. Science 2008; 319(5869): 1536-9.

126. Baek MN, Jung KH, Halder D, Choi MR, Lee BH, Lee BC, et al. Artificial microRNA-based neurokinin-1 receptor gene silencing reduces alcohol consumption in mice. Neurosci Lett 2010; 475(3): 124-8. 


\section{Annex/Aneks}

Summary of research on the miRNA expression profile in alcohol use disorder (AUD)

Zestawienie badań dotyczących profilu ekspresji miRNA w zaburzeniach związanych z używaniem alkoholu (AUD)

\begin{tabular}{|c|c|c|c|}
\hline $\begin{array}{l}\text { miRNA expression } \\
\text { Ekspresja miRNA }\end{array}$ & $\begin{array}{l}\text { Study group } \\
\text { Badana grupa }\end{array}$ & $\begin{array}{c}\text { Potential targets } \\
\text { Potencjalne cele dziatania }\end{array}$ & $\begin{array}{l}\text { References } \\
\text { Literatura }\end{array}$ \\
\hline \multicolumn{4}{|c|}{ Clinical research/Badania kliniczne } \\
\hline $\begin{array}{l}\text { Up-regulated/Wzrost } \\
\text { miR-96, miR-24, miR- } \\
\text { 136, miR-320, miR-30a, } \\
\text { miR-421 } \\
\text { Down-regulated/ } \\
\text { Obniżenie } \\
\text { miR-92b, miR-301a-3p, } \\
\text { miR-660-5p }\end{array}$ & $\begin{array}{l}20 \text { (10 F, } 10 \mathrm{M}) \text { subjects with AUD defined by } \\
\text { DSM-IV criteria (average of } 12 \text { years drinking and } \\
\text { of } 15 \text { days during the month; approx. five drinks } \\
\text { per drinking day) versus } 10 \text { controls ( } 5 \mathrm{~F}, 5 \mathrm{M}) \\
\text { Average age in both groups } 30.9 \text { years } \\
\text { Material: serum } \\
20 \text { (10 K, } 10 \mathrm{M}) \text { pacjentów z AUD wg DSM-IV } \\
\text { (średni czas picia } 12 \text { lat; średnio } 15 \mathrm{dni} \text { w ciągu } \\
\text { miesiąca; ok. pięć drinków na dzień picia) versus } \\
10 \text { osób z grupy kontrolnej ( } 5 \mathrm{~K}, 5 \mathrm{M}) \\
\text { Średnia wieku w obu grupach: } 30,9 \text { roku } \\
\text { Materiał badany: surowica }\end{array}$ & p53, TNF & {$[79]$} \\
\hline $\begin{array}{l}\text { Up-regulated/Wzrost } \\
\text { miR-203, miR-586, } \\
\text { miR-146a, miR-194, } \\
\text { miR-519b-3p, miR-665 } \\
\text { miR-586, miR-144, } \\
\text { miR-34c-5p, miR-18a, } \\
\text { miR-203, miR-586, } \\
\text { miR-580, miR-144, } \\
\text { miR-380, miR-802, } \\
\text { miR-7, miR-339-5p }\end{array}$ & $\begin{array}{l}14 \text { alcohol dependent persons defined by } \\
\text { NHMRC/WHO criteria who consumed more } \\
\text { than } 80 \mathrm{~g} \text { of ethanol per day for most of their } \\
\text { adult lives (approx. } 20 \text { years) versus } 13 \text { controls } \\
\text { excluded alcoholics with a history of poly-drug } \\
\text { abuse or other complicating conditions such } \\
\text { as cirrhosis of the liver, Wernicke-Korsakoff } \\
\text { syndrome or hepatic encephalopathy } \\
\text { Material: prefrontal cortex } \\
14 \text { pacjentów uzależnionych wg kryteriów } \\
\text { NHMRC/WHO spożywających ponad } 80 \mathrm{~g} \\
\text { alkoholu dziennie przez większość życia (ok. } 20 \\
\text { lat) versus } 13 \text { osób z grupy kontrolnej } \\
\text { Wykluczono alkoholików - nadużywających } \\
\text { narkotyków lub z chorobami takimi jak marskość } \\
\text { wątroby, zespół Wernickego-Korsakowa, } \\
\text { encefalopatia wątrobowa } \\
\text { Materiał badany: kora przedczołowa }\end{array}$ & $\begin{array}{c}\text { C110RF9 } \\
\text { CNP } \\
\text { ALCAM, SCARB2 }\end{array}$ & {$[14]$} \\
\hline $\begin{array}{l}\text { Change of expression } \\
\text { (no information on } \\
\text { direction)/Zmiana } \\
\text { ekspresji (brak } \\
\text { informacji o kierunku) } \\
\text { miR-10a-5p, miR-1290, } \\
\text { miR-4488 }\end{array}$ & $\begin{array}{c}60 \text { alcohol dependent patients assessed using } \\
\text { the Semi-Structured Assessment for Drug } \\
\text { Dependence and Alcoholism versus } 60 \text { controls } \\
\text { Co-morbid other substance use disorders was } \\
\text { found in } 88.3 \% \text { of alcohol dependent patients } \\
\text { Material: saliva } \\
60 \text { osób uzależnionych od alkoholu wg Semi- } \\
\text {-Structured Assessment for Drug Dependence } \\
\text { and Alcoholism versus } 60 \text { osób z grupy kontrolnej } \\
\text { Współwystępowanie zaburzeń związanych } \\
\text { z używaniem substancji psychoaktywnych } \\
\text { stwierdzono u 88,3\% uzależnionych od alkoholu } \\
\text { Materiał badany: ślina }\end{array}$ & $\begin{array}{l}\text { Genes involved in DNA } \\
\text { binding, alternative } \\
\text { splicing and calcium- } \\
\text { dependent cell-adhesion } \\
\text { Geny zaangażowane } \\
\text { w wiązanie DNA, } \\
\text { alternatywny splicing, } \\
\text { adhezję komórkową } \\
\text { zależną od wapnia }\end{array}$ & {$[83]$} \\
\hline $\begin{array}{l}\text { Up-regulated/Wzrost } \\
\text { miR-506, miR-1285, } \\
\text { miR-512-3p, miR-138, } \\
\text { miR-1273, miR-485-5p, } \\
\text { miR-4254, miR-4312, } \\
\text { miR-3127, miR-620 } \\
\text { Down-regulated/ } \\
\text { Obniżenie } \\
\text { miR-767-5p, miR-4262, } \\
\text { miR-3908, miR-548c-3p, } \\
\text { miR-548a-5p, miR-124, } \\
\text { miRPlus-C1114, miR-550 }\end{array}$ & $\begin{array}{c}78 \text { male with alcoholic cardiomyopathy and } \\
\text { a history of alcohol consumption of }>10 \text { years } \\
(>125 \text { g/day) versus } 78 \text { healthy men } \\
\text { Age: } 45-60 \text { years } \\
\text { Material: plasma } \\
78 \text { mężczyzn z kardiomiopatią alkoholową, czas } \\
\text { spożywania alkoholu > } 10 \text { lat ( }>125 \text { g/dobę) } \\
\text { versus } 78 \text { zdrowych ochotników } \\
\text { Wiek } 45-60 \text { lat } \\
\text { Materiał badany: osocze }\end{array}$ & PPAR & {$[109]$} \\
\hline
\end{tabular}


Annex. Cont.

Aneks. Cd.

\begin{tabular}{|c|c|c|c|}
\hline $\begin{array}{l}\text { miRNA expression } \\
\text { Ekspresja miRNA }\end{array}$ & $\begin{array}{l}\text { Study group } \\
\text { Badana grupa }\end{array}$ & $\begin{array}{c}\text { Potential targets } \\
\text { Potencjalne cele dziatania }\end{array}$ & $\begin{array}{l}\text { References } \\
\text { Literatura }\end{array}$ \\
\hline $\begin{array}{l}\text { Up-regulated/Wzrost } \\
\text { miR-182 }\end{array}$ & $\begin{array}{c}13 \text { patients with alcoholic hepatitis and } 5 \text { with } \\
\text { alcoholic liver cirrhosis, confirmed by histological } \\
\text { diagnostics (alcohol consumption }>60 \text { g/day } \\
\text { previous to study) versus controls } \\
\text { Exclusion criteria: causes of liver disease other } \\
\text { than alcohol consumption) } \\
\text { Material: serum, liver biopsy } \\
13 \text { pacjentów z alkoholowym zapaleniem } \\
\text { wątroby oraz } 5 \text { z alkoholową marskością wątroby } \\
\text { potwierdzoną diagnozą histologiczną (spożywanie } \\
\text { alkoholu > } 60 \text { g/dobę przed przystąpieniem do } \\
\text { badania) versus osoby z grupy kontrolnej } \\
\text { Kryterium wykluczenia: przyczyna choroby } \\
\text { wątroby inna niż alkoholowa } \\
\text { Materiał badany: surowica, bioptat wątroby }\end{array}$ & $\begin{array}{l}\text { SLC1A1, Ccl20, Mcp-1, } \\
\text { Bcl2 }\end{array}$ & [98] \\
\hline $\begin{array}{l}\text { Up-regulated/Wzrost } \\
\text { miR-192, miR-30a }\end{array}$ & $\begin{array}{c}14 \text { patients with different stage of alcoholic } \\
\text { hepatitis according to the guidelines } \\
\text { of the American College of Gastroenterology } \\
\text { versus } 10 \text { controls } \\
\text { Material: serum } \\
14 \text { pacjentów w różnych stadiach alkoholowego } \\
\text { zapalenia wątroby wg wytycznych American } \\
\text { College of Gastroenterology versus } 10 \text { osób } \\
\text { z grupy kontrolnej } \\
\text { Materiał badany: surowica }\end{array}$ & $\begin{array}{l}\text { EREG, DYRK3, LPAR4, } \\
\text { TNRC6A, YAF2, PHTF2 }\end{array}$ & [97] \\
\hline $\begin{array}{l}\text { Up-regulated } \\
\text { miR-10a, miR-21 after } \\
\text { exposure to stress in } \\
\text { case of heavy drinkers } \\
\text { group } \\
\text { Wzrost } \\
\text { miR-10a, miR-21 po } \\
\text { ekspozycji na stres tylko } \\
\text { w grupie intensywnie } \\
\text { pijących }\end{array}$ & $\begin{array}{c}11 \text { (3 F, } 8 \mathrm{M} \text { ) heavy drinkers defined by DSM-IV } \\
\text { criteria (> } 8 \text { number of standard drinks per week } \\
\text { for } \mathrm{F} \text { and > } 15 \text { for M; average AUDIT score } 13.1 \text { ) } \\
\text { versus } 11 \text { control moderate drinkers (< } 7 \text { number } \\
\text { of standard drinks per week for F, < } 14 \text { for M; } \\
\text { average AUDIT score } 4.5) \\
\text { Material: whole blood } \\
11 \text { (3 K, } 8 \mathrm{M} \text { ) pacjentów intensywnie pijących } \\
\text { wg kryteriów DSM-IV (> } 8 \text { standardowych porcji/ } \\
\text { tydzień w przypadku K oraz > } 15 \text { w przypadku M; } \\
\text { średni wynik AUDIT 13,1) versus } 11 \text { osób z grupy } \\
\text { kontrolnej umiarkowanie pijących } \\
\text { (<7 standardowych porcji/tydzień w przypadku K, } \\
\text { < } 14 \text { w przypadku M; średni wynik AUDIT 4,5) } \\
\text { Materiał badany: krew pełna }\end{array}$ & $\begin{array}{c}\text { Genes encode } \\
\text { components of } \\
\text { the TRBP-associated } \\
\text { complex } \\
\text { Geny kodujące składniki } \\
\text { kompleksu związanego } \\
\text { z białkiem wiążącym } \\
\text { TAR-RNA }\end{array}$ & [61] \\
\hline \multicolumn{4}{|c|}{ Animal model/Model zwierzęcy } \\
\hline $\begin{array}{l}\text { Up-regulated/Wzrost } \\
\text { miR-30a-5p, miR-195, } \\
\text { miR-124 }\end{array}$ & $\begin{array}{c}\text { Episodic heavy drinking model (mice underwent } \\
\text { of } 21 \text { sessions of } 24 \mathrm{~h} \text { and } 7 \text { week access to } 20 \% \\
\text { alcohol) } \\
\text { Material: mPFC } \\
\text { Model epizodycznego intensywnego picia (myszy } \\
\text { poddane } 21 \text { sesjom z 24-godzinnym dostępem do } \\
20 \% \text { alkoholu przez } 7 \text { tygodni) } \\
\text { Materiał badany: mPFC }\end{array}$ & BDNF & [59] \\
\hline $\begin{array}{l}\text { Down-regulated } \\
\text { miR-124a in DLS, no } \\
\text { change in the DMS } \\
\text { Obniżenie } \\
\text { miR-124a w DLS, bez } \\
\text { zmian w DMS }\end{array}$ & $\begin{array}{c}\text { Voluntary alcohol intake model (Wistar rats with } \\
\text { access to } 5 \% \text { ethanol for } 15 \text { days versus controls, } \\
\text { size of groups } 7-9 \text { ) } \\
\text { Material: DLS, DMS } \\
\text { Model dobrowolnego spożycia alkoholu (szczury } \\
\text { Wistar z dostępem do } 5 \% \text { etanolu przez } 15 \text { dni } \\
\text { versus osobniki z grupy kontrolnej, liczebność } \\
\text { grup 7-9) } \\
\text { Materiał badany: DLS, DMS }\end{array}$ & BDNF & [15] \\
\hline
\end{tabular}


Annex. Cont.

Aneks. Cd.

\begin{tabular}{|c|c|c|c|}
\hline $\begin{array}{l}\text { miRNA expression } \\
\text { Ekspresja miRNA }\end{array}$ & $\begin{array}{l}\text { Study group } \\
\text { Badana grupa }\end{array}$ & $\begin{array}{c}\text { Potential targets } \\
\text { Potencjalne cele działania }\end{array}$ & $\begin{array}{l}\text { References } \\
\text { Literatura }\end{array}$ \\
\hline $\begin{array}{l}\text { Down-regulated } \\
\text { miR-382 in the NAc } \\
\text { Obniżenie } \\
\text { miR-382 w NAc }\end{array}$ & $\begin{array}{c}18 \text { male rats divided into two groups: receiving } \\
500 \mu \text { of salineor or of alcohol ( } 1 \mathrm{~g} / \mathrm{kg}) \text { for } 7 \text { days } \\
\text { Material: NAc } \\
18 \text { samców szczurów podzielonych na dwie grupy } \\
\text { otrzymujące: } 500 \mu \mathrm{l} \text { soli fizjologicznej lub alkohol } \\
(1 \mathrm{~g} / \mathrm{kg}) \text { przez } 7 \mathrm{dni} \\
\text { Materiał badany: NAc }\end{array}$ & DRD1, DeltaFosB & [36] \\
\hline $\begin{array}{l}\text { Up-regulated } \\
\text { miR-206 in the mPFC } \\
\text { contributes to escalated } \\
\text { alcohol consumption } \\
\text { Wzrost } \\
\text { miR-206 w mPFC } \\
\text { związany z nasileniem } \\
\text { spożywania alkoholu }\end{array}$ & $\begin{array}{c}\text { Alcohol dependence model (8 male Wistar } \\
\text { rats receiving } 10 \% \text { alcohol with reinforcement } \\
\text { schedule versus } 8 \text { controls; assessment after } \\
\text { withdrawal symptoms occur) } \\
\text { Material: mPFC } \\
\text { Model uzależnienia od alkoholu (8 samców szczurów } \\
\text { Wistar otrzymujących } 10 \% \text { alkohol wg schematu } \\
\text { ciągłego wzmocnienia versus } 8 \text { osobników kontrolnych; } \\
\text { ocena po wystąpieniu objawów odstawienia) } \\
\text { Materiał badany: mPFC }\end{array}$ & BDNF & [58] \\
\hline $\begin{array}{l}\text { Up-regulated/Wzrost } \\
\text { miR-155 }\end{array}$ & $\begin{array}{l}\text { Alcoholic liver disease model (mice received 5\% } \\
\text { ethanol for } 4 \text { weeks versus controls; group size: 15-30) } \\
\text { Material: Kupffer cells, macrophages } \\
\text { Model alkoholowej choroby wątroby (myszy } \\
\text { karmione } 5 \% \text { alkoholem przez } 4 \text { tygodnie versus } \\
\text { osobniki kontrolne; liczebność grup: 15-30) } \\
\text { Materiał badany: komórki Kupffera, makrofagi }\end{array}$ & TNF $\alpha$ & [87] \\
\hline $\begin{array}{l}\text { Up-regulated/Wzrost } \\
\text { miR-705, miR-1224 } \\
\text { Down-regulated/ } \\
\text { Obniżenie } \\
\text { miR-27b, miR-214, } \\
\text { miR-199a-3p, miR-182, } \\
\text { miR-183, miR-200a, } \\
\text { miR-322 }\end{array}$ & $\begin{array}{c}\text { Alcoholic steatohepatitis model (mice received } \\
4.5 \% \text { ethanol for } 5 \text { weeks versus controls; group } \\
\text { size: } 3-6 \text { ) } \\
\text { Material: liver } \\
\text { Model alkoholowego stłuszczenia wątroby (myszy } \\
\text { karmione } 4,5 \% \text { etanolem przez } 5 \text { tygodni versus } \\
\text { osobniki kontrolne; liczebność grup: } 3-6 \text { ) } \\
\text { Materiał badany: wątroba }\end{array}$ & $\mathrm{TNF} \alpha$ & [88] \\
\hline $\begin{array}{l}\text { Up-regulated/Wzrost } \\
\text { miR-34a }\end{array}$ & $\begin{array}{c}\text { Alcoholic liver disease model (mice were infused } \\
\text { with increasing dose of ethanol of } 22.7 \text { to } 35 \mathrm{~g} / \\
\text { kg per day for } 4 \text { weeks) } \\
\text { Material: liver } \\
\text { Model alkoholowej choroby wątroby } \\
\text { (myszy poddane infuzji rosnących dawek alkoholu } \\
\text { od 22,7 do } 35 \mathrm{~g} / \mathrm{kg} \text { dobę przez } 4 \text { tygodnie) } \\
\text { Materiał badany: wątroba }\end{array}$ & CASP2, SIRT1 & [89] \\
\hline $\begin{array}{l}\text { Up-regulated/Wzrost } \\
\text { miR-490, miR-185 } \\
\text { Down-regulated/ } \\
\text { Obniżenie } \\
\text { miR-199a-3p, miR-214 }\end{array}$ & $\begin{array}{l}\text { Alcoholic steatohepatitis model (rats were } \\
\text { received } 17.68 \mathrm{ml} / \mathrm{kg} 56 \% \text { alcohol once per day } \\
\text { for } 16 \text { weeks versus control; group size: } 12 \text { ) } \\
\text { Material: liver tissues, serum } \\
\text { Model alkoholowego stłuszczenia wątroby } \\
\text { (szczury otrzymujące } 17,68 \mathrm{ml} / \mathrm{kg} 56 \% \text { alkoholu } \\
\text { raz dziennie przez } 16 \text { tygodni versus grupa } \\
\text { kontrolna; liczebność grup: } 12 \text { osobników) } \\
\text { Materiał badany: wątroba, surowica }\end{array}$ & Gcom1, Zmynd11, Zfp423 & [92] \\
\hline $\begin{array}{l}\text { Up-regulated/Wzrost } \\
\text { miR-21, miR-34a }\end{array}$ & $\begin{array}{c}\text { Alcoholic liver injury model (mice were infused } \\
\text { with increasing dose of ethanol from } 22.7 \text { to } 35 \\
\text { g/kg per day for } 4 \text { weeks versus controls) } \\
\text { Material: liver, plasma } \\
\text { Model alkoholowego uszkodzenia wątroby } \\
\text { (myszy poddano infuzji rosnących dawek } \\
\text { alkoholu 22,7-35 g/kg dziennie przez } 4 \text { tygodnie } \\
\text { versus osobniki kontrolne) } \\
\text { Materiał badany: wątroba, osocze }\end{array}$ & FASLG, DR5 & [94] \\
\hline
\end{tabular}


Annex. Cont.

Aneks. Cd.

\begin{tabular}{|c|c|c|c|}
\hline $\begin{array}{l}\text { miRNA expression } \\
\text { Ekspresja miRNA }\end{array}$ & $\begin{array}{l}\text { Study group } \\
\text { Badana grupa }\end{array}$ & $\begin{array}{c}\text { Potential targets } \\
\text { Potencjalne cele działania }\end{array}$ & $\begin{array}{l}\text { References } \\
\text { Literatura }\end{array}$ \\
\hline $\begin{array}{l}\text { Up-regulated/Wzrost } \\
\text { miR-192, miR-122, } \\
\text { miR-30a }\end{array}$ & $\begin{array}{c}\text { Alcoholic hepatitis model (12 mice received 5\% } \\
\text { ethanol for } 4 \text { weeks versus } 12 \text { controls) } \\
\text { Material: liver, serum } \\
\text { Model alkoholowego zapalenia wątroby (12 } \\
\text { myszy otrzymujących } 5 \% \text { etanol przez } 4 \text { tygodnie } \\
\text { versus } 12 \text { osobników kontrolnych) } \\
\text { Materiał badany: wątroba, surowica }\end{array}$ & $\begin{array}{l}\text { EREG, DYRK3, LPAR4, } \\
\text { TNRC6A, YAF2, PHTF2 }\end{array}$ & [97] \\
\hline $\begin{array}{l}\text { Up-regulated } \\
\text { miR-155 only in } \\
\text { the group of chronic } \\
\text { alcohol feeding } \\
\text { Wzrost } \\
\text { miR-155 tylko w grupie } \\
\text { zwierząt przewlekle } \\
\text { karmionych alkoholem }\end{array}$ & $\begin{array}{l}\text { Chronic alcohol feeding model (mice received } \\
\text { 5\% ethanol for } 5 \text { weeks) and acute alcohol binge } \\
\text { model (mice received } 5 \mathrm{~g} / \mathrm{kg} 50 \% \text { ethanol for } \\
3 \text { consecutive days) versus controls } \\
\text { Material: small bowel } \\
\text { Model przewlekłego spożywania alkoholu } \\
\text { (myszy otrzymujące } 5 \% \text { etanol przez } 5 \text { tygodni) } \\
\text { oraz model ostrego spożywania alkoholu } \\
\text { (myszy otrzymujące } 5 \text { g/kg } 50 \% \text { etanolu przez } \\
3 \text { kolejne dni) versus osobniki kontrolne } \\
\text { Materiał badany: jelito cienkie }\end{array}$ & $\mathrm{TNF} \alpha$ & [100] \\
\hline
\end{tabular}

AUDIT - Alcohol Use Disorders Identification Test, ALCAM - activated leukocyte cell adhesion molecule, Bcl2 - apoptosis regulator, BDNF - brain derived neurotrophic factor, CASP2 - caspase 2, C11ORF9 - myelin regulatory factor, Cc120-C-C motif chemokine ligand 20, CNP-2',3'-cyclic nucleotide 3' phosphodiesterase, DeltaFosB - protein Delta FosB gene, DLS - dorsalateral striatum, DMS - dorso-medial striatum, DRD 1 - dopamine receptor $D_{1}$, DR5 - death receptor 5, DYRK3 - dual specificity tyrosine $(Y)$ phosphorylation regulated kinase 3, EREG - epiregulin, FASLG - Fas ligand, Gcom 1-GRINL 1A complex Locus 1, LPAR4 - lysophosphatidic acid receptor 4, Mcp - monocyte chemoattractant protein, MPFC - medial prefrontal cortex, NAc - nucleus accumbens, PHTF2 - putative homeodomain transcription factor 2, PLP1 - proteolipid protein 1 gene, PPAR - peroxisome proliferator activated receptor, SCARB2 - scavenger receptor class B member 2, SIC1A1 - solute carrier family 1 member 1, SIRT1 - sirtuin 1, TNF-tumor necrosis factor, TNRC6A - trinucleotide repeat containing adaptor 6A, YY1 - YY1 transcription factor, Zfp 423 - zinc finger protein 423.

AUDIT - Test Rozpoznawania Zaburzeń Związanych ze Spożywaniem Alkoholu, ALCAM - gen kodujący cząsteczkę adhezyjna zaktywowanych leukocytów, Bcl2 - gen kodujacy regulator apoptozy, BDNF - gen neurotroficznego czynnika pochodzenia mózgowego, CASP2 - gen kodujący kaspazę 2, C110RF9 - gen czynnika regulacyjnego mieliny, Ccl20 - gen kodujacy ligand chemokiny 20 (motyw CC), CNP - gen kodujący 2',3'-cykliczny nukleotyd 3'fosfodiesterazy, DeltaFosB - gen kodujący biatko Delta FosB, DLS - prażkowie grzbietowo-boczne, DMS - prążkowie grzbietowo-przyśrodkowe, DRD 1 - gen receptora dopaminy $D_{1}$, DR5 - gen kodujący receptor śmierci 5, DYRK3 - gen kodujący kinazę 3 regulowaną przez fosforylację tyrozyny $(Y)$ o podwójnej specyficzności, EREG - gen kodujący epiregulinę, FASLG - gen kodujący ligand Fas, Gcom 1 - gen biatka fuzyjnego GRINL 1A, LPAR4 - gen receptora kwasu lizofosfatydowego, Mcp - gen kodujacy białko chemotaktyczne monocytów, mPFC - przyśrodkowa kora przedczołowa, NAc-jądro pótleżące, PHTF2 - czynnik transkrypcyjny homeodomeny 2, PLP1 - gen kodujacy biatko proteolipidowe 1, PPAR - gen kodujący receptory aktywowane przez proliferatory peroksysomów, SCARB2 - gen kodujący lizosomalne białko błonowe 2, SIC1A1 - gen kodujący rozpuszczalny nośnik podrodziny A rodziny 1, SIRT1 - gen sirtuiny 1, TNF - gen kodujący czynnik martwicy nowotworów, TNRC6A - gen kodujący biatko 6A zawierające powtórzenia trinukleotydowe, YY1 - gen czynnika transkrypcyjnego YY1, Zfp 423 - gen biatka palca cynkowego 423. 
